\title{
Chemical assessment of mycotoxin contaminants and veterinary residues in Costa Rican animal feed
}

\author{
Astrid Leiva', Geovanna Méndez ${ }^{1}$, César Rodríguez², Andrea Molina ${ }^{1,3}$ and Fabio Granados-Chinchilla ${ }^{1 *}$ (D)
}

\begin{abstract}
Background: When present in animal feedstuff, mycotoxins contaminants and antibiotic residues can have negative implications for animal production and Public Health, including the transmission of carcinogenic compounds and the selection of antibiotic resistant bacteria, respectively. So far there are no available methods in which both mycotoxins and antibiotic residues are analyzed using a parallel extraction approach. To address this issue, we developed a LC/MS methodology with high sensitivity ( 0.005 to 6.42 and 24.55 to $132.73 \mu \mathrm{g} \mathrm{kg}^{-1}$ for mycotoxins and antimicrobials) and specificity (unique target ion mass/charge) that allows the detection of 26 mycotoxins and 23 antibiotic residues in animal feedstuff and validated it through the determination of these analytes in 294 animal feed and feed ingredient samples in the framework of a country-wide surveillance program. Two hundred and five of these samples were analyzed for mycotoxins and 89 for antibiotics.

Findings: Fumonisin was the most frequently toxin found, with $\mathrm{FB}_{1}$ and $\mathrm{FB}_{2}$ presenting prevalences of 50 and $52 \%$ and maximum concentrations of $14,927.61$ and $8646.67 \mathrm{\mu g} \mathrm{kg}^{-1}$, respectively. Other toxins, including diacetoxyscirpenol $n=4 / 101$ (3.96\%), fusarenon-X $n=2 / 101$ (1.98\%), citrinin $n=2(1.98 \%)$, and patulin $n=1(0.99 \%)$ were rarely found. Toxicologically relevant concentrations of toxin metabolites, such as HT-2 (6.38-485.49 $\left.\mathrm{\mu g} \mathrm{kg}^{-1}\right)$ and 3-/15acetoxydeoxynivalenol (877.89-3236.56/5.44-1685.3 $\mathrm{g} \mathrm{kg}^{-1}$ ), were also found. Few samples exceeded threshold mycotoxin concentrations defined in current EU guidelines. Dairy cattle and swine feeds included the higher number of samples exceeding guideline values ( $n=6$ and $n=5$, respectively). From the total of samples analysed for antibiotics, $7.7 \%(n=7 / 89)$ were classified as medicated for poultry and pigs. Unexpectedly, $57 \%$ of these medicated samples contained no detectable antibiotics $(n=4 / 7)$. The remaining $43 \%$ of the samples $(n=3 / 7)$ presented inconsistencies regarding the concentration of analytes declared on the labels or the antibiotics found. Likewise 74.6\% ( $n=50 / 67)$ of the non-medicated feed samples analyzed had antibiotic residues. Additionally, we analyzed commercial monensin standards for purity and evaluate batch-to-batch flushing feed industry practices.

Conclusions: Herein we report the results for a year-wide analysis for mycotoxins and antibiotics in feed samples. Mycotoxins, several metabolites, and the occurrence of these emerging contaminants were evaluated and antibiotic residues in non-medicated feed samples were found using a targeted MS-based LC approach. This validated multianalyte method is expected to facilitate the monitoring and surveillance of contaminants, from natural and anthropogenic origin, in animal feed.
\end{abstract}

Keywords: Mycotoxins, Antibiotics, Animal feed, LC/MS, Food safety

\footnotetext{
*Correspondence: fabio.granados@ucr.ac.cr

${ }^{1}$ Centro de Investigación en Nutrición Animal (CINA), Universidad de Costa

Rica, 11501-2060 Ciudad Universitaria Rodrigo Facio, San José, Costa Rica

Full list of author information is available at the end of the article
}

(C) The Author(s). 2019 Open Access This article is distributed under the terms of the Creative Commons Attribution 4.0 International License (http://creativecommons.org/licenses/by/4.0/), which permits unrestricted use, distribution, and reproduction in any medium, provided you give appropriate credit to the original author(s) and the source, provide a link to the Creative Commons license, and indicate if changes were made. 


\section{Introduction}

Mycotoxins and antibiotics represent natural and intentional contaminants of animal feed (Pinotti et al. 2016; Tang et al. 2017), respectively. The former group of compounds are produced by several fungal species that grow, during the pre- and postharvest stages of the food chain, on cereals, grains, nuts, spices, fruits and by-products commonly used as raw material in animal feed elaboration (Pinotti et al. 2016; Alshannaq and Yu 2017).

The most important mycotoxins contaminating animal feed include the aflatoxins $B_{1}, B_{2}, G_{1}$, and $G_{2}$, patulin, citrinin, ochratoxin $A$ and $B$, fumonisin $B_{1}$, Fumonisin $B_{2}$, Type A trichothecenes, zearalenone, and emerging mycotoxins such as enniatins (Eskola et al. 2018; Marín et al. 2013; Wu et al. 2014). Most of these substances are stable and cannot be eliminated by common feed and food production processes (Karlovsky et al. 2016; Pinotti et al. 2016), hence they can diminish animal productivity or exert toxic effects on animals (Bezerra da Rocha et al. 2014; De Ruyck et al. 2015; Zain 2011), such as cancer (i.e. aflatoxin $B_{1}$ and fumonisin $B_{1}$, Ostry et al. 2017). Moreover, since they can accumulate in meat, milk, or eggs, they have the potential to reach and affect the health of end consumers (Bozzo et al. 2011; Alshannaq and Yu. 2017). For these reasons national and international agencies regulate the presence of mycotoxins in animal feedstuff and good manufacturing practices have been implemented to avoid or reduce mycotoxin contamination in food and feed (Ndemera et al. 2018; CODEX 2014).

In contrast to mycotoxins, which are natural contaminants and therefore difficult to avoid in raw materials and animal feed, antibiotics such as monensin and tetracycline are intentionally added to animal feed for prophylaxis and metaphylaxis purposes (Anadón et al. 2018; Rojek-Podgórska 2016) or as growth promoters to improve feed efficiency (Cancho Grande et al. 2000; Rojek-Podgórska 2016). It has been shown that the exposure of food-producing animals to antibiotics leads to allergic reactions and the selection of antimicrobial resistant bacteria (FAO 2002; WHO 2015). Consequently, strict vigilance, tutelage, follow-up, and regulation protocols have been established in feed manufacturing and animal production (COMIECO 2012; European Commission 2001; European Commission 2004; FAO 2002; FDA 2018; MAG 1985; WHO 2015).

Despite the paramount importance of contaminant monitoring on feed quality and Public Health (van der Fels-Klerx et al. 2016a, b), there is scarce data on the occurrence and co-occurrence of mycotoxins and antibiotics in feed ingredients and animal feed produced in developing economies.

LC-MS methods have been used for screening, preparative, and confirmation purposes; in animal feed different LC-MS methods have been developed for multiple antibiotic residues analyses (Boix et al. 2014; Granados-Chinchilla and Rodríguez 2017). Also, multiple-mycotoxin methods have been applied in animal feed (Njumbe et al. 2015; Granados-Chinchilla 2017). So far few available methods can assess both antibiotic residues and mycotoxins using a single extraction approach and a solvent system during chromatography. To tackle this gap, we developed a LC/MS-based methodology that allows the analysis of 26 mycotoxins and 23 antibiotic residues in these matrices with high sensitivity and specificity. We applied our method to 294 samples collected in a country-wide surveillance program and found mycotoxins and antibiotics that are not in accordance with the respective regulations.

\section{Methods \\ Feed sampling}

Selection of feed and feed ingredients to be tested, number of samples, and sampling sites were chosen by feed control officials. Selection considered the most common feedstuffs used in Costa Rica, import and export regulations, contamination risk factors, the productivity of the feed industry, and the risk for human and animal health associated with each feed or feed ingredient. Sampling was performed following the Association of American Feed Control Officials recommendations for mycotoxin test object collection (AAFCO 2017). Samples were analyzed immediately upon arrival at the laboratory. Samples were quartered and sieved to a final particle size of $1 \mathrm{~mm}$.

\section{Mycotoxins}

A total of $n=205$ animal feed and feed ingredient samples of about $5 \mathrm{~kg}$ were received in the laboratory for analysis. The samples collected represent $n=57$ Costa Rican feed manufacturing plants during 2018 with the collaboration of government official inspectors as part of an annual countrywide surveillance program. Samples included dairy cattle feed $(n=64$; $31.2 \%)$, swine feed $(n=19 ; 9.3 \%)$, corn meal $(n=18$; $8.8 \%)$, beef cattle feed $(n=14 ; 6.8 \%)$, soybean meal ( $n=12 ; 5.9 \%)$, calf feed $(n=11 ; 5.4 \%)$, poultry feed $(n=11 ; 5.4 \%)$, poultry layer feed $(n=9 ; 4.4 \%)$, forage ( $n=8 ; 3.9 \%)$, wheat middlings $(n=6 ; 2.9 \%)$, horse feed $(n=4 ; 2.0 \%)$, dog dry food, cat dry food, fish feed (Tilapia and Trout feed), shrimp feed $(n=3 ; 1.5 \%$ each), palm kernel meal, rice meal, sheep feed, and almond meal ( $n=2 ; 1 \%$, each), banana peel, cassava meal, citrus pulp, distillers dried grains, rice bran, and rodent feed ( $n=1 ; 0.5 \%$, each). 


\section{Antimicrobial drugs}

In the same fashion, as mycotoxin analysis, $n=89$ samples were collected from $n=33$ Costa Rican feed manufacturing plants for antibiotic residue analyses. This subset of samples included feed for swine feed $(n=29$; $32.6 \% ; n=5 / 29$ starter, $n=22 / 29$ growers, and $n=2 / 29$ finishers), poultry layer feed ( $n=20 ; 22.5 \%)$, poultry feed ( $n=17 ; 19.1 \% ; n=4 / 17$ finishers, $n=6 / 17$ growers, and $n=7 / 17$ starters), fish feed (Tilapia and Trout feed, $n=4$ and $n=1 ; 4.5$ and $1.1 \%$, respectively), shrimp feed $(n=3$; $3.3 \%)$, dairy cattle feed $(n=3 ; 3.3 \%)$, and horse feed $(n=$ $1 ; 1.1 \%)$. Additionally, $7.9 \%(n=7)$, of the samples correspond to feed ingredients (i.e., a calcium salt and ground corn) used during batch flushing. Finally, 4.5\% $(n=4)$ commercial imported feed grade monensin samples were subjected to test for conformity.

\section{Reagents}

LC grade acetonitrile (ACN, catalog number 100029, LiChrosolv $\left.{ }^{\circ}\right)$, methanol $(\mathrm{MeOH}$, catalog number 106035, LiChrosolv $^{\circ}$ ) and ethanol (EtOH, catalog number 111727, LiChrosolv ${ }^{\circ}$ ) formic acid (FA, catalog number 100241, 98$100 \%$, EMSURE ${ }^{\circ}$ ACS, Reag. Ph Eur) were acquired from Merck Millipore (Merck KGaA, Darmstadt, Germany). Sodium chloride (catalog number 31434), potassium chloride (catalog number P3911), sodium phosphate dibasic (catalog S9763), and potassium phosphate monobasic (catalog number 1551139) were acquired from Sigma-Aldrich (St. Louis, Mo, USA). Ultra-High Pure Nitrogen was purchased from Praxair Technology Inc. (Alajuela, Costa Rica). Ultrapure water [type I, $0.055 \mu \mathrm{S} \mathrm{cm}{ }^{-1}$ at $\left.25^{\circ} \mathrm{C}, 5 \mu \mathrm{g} \mathrm{L}^{-1} \mathrm{TOC}\right]$ was obtained using an A10 Milli-Q Advantage system and an Elix 35 system (Merck KGaA, Darmstadt Germany). Trilogy (Washington, MO, USA) solutions for ochratoxin A (catalog number TSL-504), zearalenone (catalog number TSL-401), HT-2 toxin (catalog number TSL-333), citrinin (catalog number TS-904), T-2 toxin (catalog number TSL-314), fumonisin $B_{1}$ and $B_{2}$ (catalog number TSL-202), patulin (catalog number TSL-601), and trichothecenes (catalog number TS-307) were used as standards. Analytical pure standards for fumonisin $B_{3}$ (catalog number 32606), ennantin $B_{1}$ (catalog number E5286), ennantin B (catalog number E5411), $\beta$-zearalenol (catalog number Z2000), $\alpha$-zearalenol (catalog number Z0166), sterigmatocystin (catalog number 53255), aflatoxin $M_{1}$ (catalog number A6428), ochratoxin B (catalog number 32411), narasin (catalog number N1271), chloramphenicol (catalog number C0378), oxytetracycline (catalog number O4636), florfenicol (catalog number F1427), demeclocycline (catalog number D6140), tylosin (catalog number T6134), tetracycline (catalog number T3258), monensin (catalog number M5273), minocycline (catalog number M9511), erythromycin (catalog number 856193), chlortetracycline (catalog number
46133), doxycycline (catalog number D9891), sulfamethazine (catalog number S6256), penicillin G (P3032), lincomycin (catalog number 31727), spectinomycin (catalog number 46738), ciprofloxacin- $\mathrm{d}_{8}$ (VETRANAL $^{\mathrm{TM}}$, catalog number 32982), flunixin- $\mathrm{d}_{3} \quad$ (VETRANAL $^{\mathrm{m}}$, catalog number 34083), and virginiamycin $S_{1}$ (catalog number V4140) and $M_{1}$ (catalog number V2753) were purchased from Sigma-Aldrich. Methacycline (catalog number 3963-95-9), 4-epioxytetracycline, 4-epichlortetracycline, 4-epianhydrotetracycline, and 4-epitetracycline analytical standards were purchased from ACROS Organics (New Jersey, USA). All standards were used to construct five-point calibration curves (from 1.00 to $6.25 \times 10^{-2} \mathrm{mg}$ $\mathrm{L}^{-1}$ for each mycotoxin, Table 1 ). Likewise, a standard containing exactly $1.00 \mathrm{mg} \mathrm{L}^{-1}$ was used to obtain response factors $\left(\right.$ Area $_{s t d} /$ Concentration $\left._{\text {std }}\right)$ for each veterinary drug. Pure standards were used, as well, to assess the base, molecular and target ion of each compound for quantification purposes. TR-MT100 Trilogy Multitoxin Reference Material MT-C-999-G (naturally contaminated cornmeal) was tested in parallel for quality control purposes during each batch of analyses. A sample of medicated dairy feed (AAFCO check sample 201,530) was used similarly during the veterinary drug assays. Chromatographic quality nitrogen was generated with a PEAK Scientific generator (NM32LA, Inchinnan, United Kingdom).

\section{Feed sample extraction Mycotoxins}

The extraction method was adapted from a previously reported method for cornmeal testing (Wang et al. 2013). Briefly, $25 \mathrm{~g}$ of each sample was extracted for 2 min at $18000 \mathrm{rpm}$ with $100 \mathrm{~mL}$ of an $\mathrm{ACN}: \mathrm{H}_{2} \mathrm{O}: \mathrm{CH}_{3-}$ $\mathrm{CO}_{2} \mathrm{H}$ solution with a volume ratio of 74:25:1 using an Ultra-turrax ${ }^{\oplus}$ homogenizer (T25, IKA, Werke GmbH \& Co. KG, Staufen in Breisgau, Germany). Fresh material (e.g. forages) were processed using twice the solvent volume mentioned above. The supernatant was removed and filtered by gravity through Whatman ${ }^{\odot} 541$ ashless filters (GE Health Life Sciences Little Chalfont, Buckinghamshire, UK). Then, a $2 \mathrm{~mL}$ aliquot was pipetted to a $25 \mathrm{~mL}$ volumetric flask and filled with phosphate buffer solution (PBS at $\mathrm{pH} 7.4$ containing $\mathrm{NaCl}, 150 \mathrm{mmol} \mathrm{L}^{-1}$; $\mathrm{KCl}, 2.50 \mathrm{mmol} \mathrm{L}^{-1} ; \mathrm{Na}_{2} \mathrm{HPO}_{4}, 4.50 \mathrm{mmol} \mathrm{L}^{-1} ; \mathrm{KH}_{2} \mathrm{PO}_{4}$, $\left.1.50 \mathrm{mmol} \mathrm{L}^{-1}\right)$. For sample cleanup, Oasis ${ }^{\circledR} \mathrm{HLB}$ columns (WAT094226, 3 cc, $60 \mathrm{mg}, 30 \mu \mathrm{m}$ particle size, Waters Corporation, Milford, MA, USA) were activated and conditioned with $2 \mathrm{~mL} \mathrm{MeOH}$ and equilibrated with $2 \mathrm{~mL}$ of a $\mathrm{MeOH} / \mathrm{H}_{2} \mathrm{O}$ solution (5:95 volume ratio) using a SPE 12 port vacuum manifold $\left(57,044\right.$, Visiprep ${ }^{\mathrm{Tm}}$, Supelco Inc., Bellefonte, PA, USA) operating at 15 $\mathrm{mmHg}$. Sample extracts were then passed through the columns at a flow rate of $1 \mathrm{~mL} \mathrm{~min}{ }^{-1}$. Columns were 
Table 1 Performance parameters and mass detector settings for the assessed analytes in order of increasing molar mass

\begin{tabular}{|c|c|c|c|c|c|c|c|c|}
\hline Analyte & $\begin{array}{l}\text { Molar mass, } \\
\mathrm{g} / \mathrm{mol}\end{array}$ & $\begin{array}{l}\text { Retention } \\
\text { time, min }\end{array}$ & Target ion, m/z & Fragmentor & $\begin{array}{l}\text { Dwell time, } \\
\text { ms }\end{array}$ & $\begin{array}{l}\text { Calibration curve } \\
\text { equation }{ }^{a} \text { or } \\
\text { response factor }\end{array}$ & $\begin{array}{l}\text { b Limit of } \\
\text { detection, } \mu \mathrm{g} \\
\mathrm{kg}^{-1}\left({ }^{\top} \mu g \mathrm{~L}^{-1}\right)\end{array}$ & $\begin{array}{l}\text { Limit of } \\
\text { quantification } \\
\mu \mathrm{kg}^{-1}\end{array}$ \\
\hline \multicolumn{9}{|l|}{ Mycotoxin contaminants } \\
\hline Patulin & 154.21 & 24.63 & $154.3[\mathrm{M}+]$ & 120 & 71 & $\begin{array}{l}y=\left(4.81 \times 10^{3} \pm 2.69 \times\right. \\
\left.10^{2}\right) x\end{array}$ & $0.62(10.1)$ & 1.84 \\
\hline Citrinin & 251.10 & 23.48 & $251.0[\mathrm{M}+]$ & 120 & 56 & $\begin{array}{l}y=\left(3.67 \times 10^{3} \pm 8.11 \times\right. \\
\left.10^{2}\right) x\end{array}$ & $0.34(1.9)$ & 1.03 \\
\hline Deoxynivalenol & 296.30 & 8.69 & $\begin{array}{l}297.1[\mathrm{M}+\mathrm{H}]^{+} \text {and } \\
319.0[\mathrm{M}+\mathrm{Na}]^{+}\end{array}$ & 120 & 144 & $\begin{array}{l}y=\left(1.61 \times 10^{3} \pm 4.11 \times\right. \\
\left.10^{2}\right) x\end{array}$ & $6.31(105.2)$ & 19.12 \\
\hline Aflatoxin $B_{1}$ & 312.28 & 21.11 & $313.0[\mathrm{M}+\mathrm{H}]^{+}$ & 140 & 34 & $\begin{array}{l}y=\left(2.62 \times 10^{2} \pm 3.14 \times\right. \\
\left.10^{1}\right) x\end{array}$ & $0.40(6.7)$ & 1.21 \\
\hline Nivalenol & 312.32 & 5.14 & $355.1[\mathrm{M}+2 \mathrm{Na}]^{+}$ & 140 & 143 & $\begin{array}{l}y=\left(1.73 \times 10^{2} \pm 2.10 x\right. \\
\left.10^{1}\right) x\end{array}$ & $6.42(107.0)$ & 19.45 \\
\hline Aflatoxin $B_{2}$ & 314.30 & 20.48 & $315.0[\mathrm{M}+\mathrm{H}]^{+}$ & 140 & 34 & $\begin{array}{l}y=\left(1.01 \times 10^{2} \pm 3.15 \times\right. \\
\left.10^{1}\right) x\end{array}$ & $0.14(2.3)$ & 0.42 \\
\hline Zearalenone & 318.40 & 24.67 & $319.0[\mathrm{M}+\mathrm{H}]^{+}$ & 120 & 71 & $\begin{array}{l}y=\left(6.75 \times 10^{2} \pm 3.41 \times\right. \\
\left.10^{1}\right) x\end{array}$ & $0.26(4.3)$ & 0.79 \\
\hline$\beta$-zearalenol & 320.38 & 22.16 & $321.0[\mathrm{M}+\mathrm{H}]^{+}$ & 120 & 56 & $\begin{array}{l}y=\left(1.43 \times 10^{2} \pm 2.55 \times\right. \\
\left.10^{1}\right) x\end{array}$ & $0.44(7.3)$ & 1.33 \\
\hline a-zearalenol & 320.38 & 23.07 & $321.1[\mathrm{M}+\mathrm{H}]^{+}$ & 120 & 56 & $\begin{array}{l}y=\left(4.80 \times 10^{3} \pm 2.01 \times\right. \\
\left.10^{2}\right) x\end{array}$ & $0.63(5.67)$ & 1.91 \\
\hline Sterigmatocystin & 324.30 & 25.43 & $327.1[\mathrm{M}+3 \mathrm{H}]^{+}$ & 140 & 95 & $\begin{array}{l}y=\left(7.64 \times 10^{2} \pm 5.54 \times\right. \\
\left.10^{1}\right) x\end{array}$ & $0.60(10.0)$ & 1.82 \\
\hline Aflatoxin $\mathrm{G}_{1}$ & 328.30 & 20.48 & $328.9[\mathrm{M}+\mathrm{H}]^{+}$ & 140 & 34 & $\begin{array}{l}y=\left(5.95 \times 10^{2} \pm 2.33 \times\right. \\
\left.10^{1}\right) x\end{array}$ & $0.27(4.5)$ & 0.82 \\
\hline Aflatoxin $\mathrm{M}_{1}$ & 328.27 & 19.13 & $329.0[\mathrm{M}+\mathrm{H}]^{+}$ & 140 & 34 & $\begin{array}{l}y=\left(4.02 \times 10^{3} \pm 3.61 \times\right. \\
\left.10^{2}\right) x\end{array}$ & $0.005(0.8)$ & 0.02 \\
\hline Aflatoxin $G_{2}$ & 330.30 & 19.87 & $331.0[\mathrm{M}+\mathrm{H}]^{+}$ & 140 & 34 & $\begin{array}{l}y=\left(1.10 \times 10^{2} \pm 1.12 \times\right. \\
\left.10^{7}\right) x\end{array}$ & $0.20(3.3)$ & 0.61 \\
\hline $\begin{array}{l}\text { 3- } \\
\text { acetoxydeoxynivalenol }\end{array}$ & 338.35 & 18.01 & $339.2[\mathrm{M}+\mathrm{H}]^{+}$ & 140 & 71 & $\begin{array}{l}y=\left(1.78 \times 10^{2} \pm 6.65 \times\right. \\
\left.10^{1}\right) x\end{array}$ & $0.38(6.3)$ & 1.15 \\
\hline $\begin{array}{l}15- \\
\text { acetoxydeoxynivalenol }\end{array}$ & 338.35 & 18.26 & $339.1[\mathrm{M}+\mathrm{H}]^{+}$ & 120 & 71 & $\begin{array}{l}y=\left(8.77 \times 10^{2} \pm 2.15 \times\right. \\
\left.10^{1}\right) x\end{array}$ & $0.30(5.0)$ & 0.91 \\
\hline Fusarenon-X & 354.35 & 15.74 & $355.0[\mathrm{M}+\mathrm{H}]^{+}$ & 140 & 71 & $\begin{array}{l}y=\left(1.40 \times 10^{2} \pm 1.17 \times\right. \\
\left.10^{1}\right) x\end{array}$ & $0.29(4.8)$ & 0.88 \\
\hline Diacetoxyscirpenol & 366.41 & 16.84 & $365.0\left[\mathrm{C}_{19} \mathrm{H}_{25} \mathrm{O}_{7}\right]^{+\cdot}-\mathrm{H}^{\cdot}$ & 140 & 71 & $\begin{array}{l}y=\left(8.35 \times 10^{1} \pm 4.31 \times\right. \\
\left.10^{0}\right) x\end{array}$ & $0.32(5.3)$ & 0.97 \\
\hline Ochratoxin B & 369.37 & 22.71 & $370.0[\mathrm{M}+\mathrm{H}]^{+}$ & 120 & 56 & $\begin{array}{l}y=\left(1.23 \times 10^{2} \pm 1.15 \times\right. \\
\left.10^{1}\right) x\end{array}$ & $0.21(3.5)$ & 0.64 \\
\hline Neosolaniol & 382.41 & 20.79 & $384.2[\mathrm{M}+2 \mathrm{H}]^{+}$ & 140 & 34 & $\begin{array}{l}y=\left(8.74 \times 10^{2} \pm 9.14 \times\right. \\
\left.10^{1}\right) x\end{array}$ & $0.61(10.2)$ & 1.85 \\
\hline Ochratoxin A & 405.40 & 24.35 & $404.0[\mathrm{M}+\mathrm{H}]^{+}$ & 120 & 71 & $\begin{array}{l}y=\left(1.19 \times 10^{2} \pm 5.09 \times\right. \\
\left.10^{1}\right) x\end{array}$ & $0.16(2.7)$ & 0.48 \\
\hline HT-2 toxin & 424.48 & 21.38 & $425.1[\mathrm{M}+\mathrm{H}]^{+}$ & 140 & 56 & $\begin{array}{l}y=\left(1.06 \times 10^{3} \pm 2.19 \times\right. \\
\left.10^{2}\right) x\end{array}$ & $0.32(5.3)$ & 0.97 \\
\hline T-2 toxin & 466.47 & 22.66 & $484.3\left[\mathrm{M}+\mathrm{NH}_{4}\right]^{+}$ & 140 & 71 & $\begin{array}{l}y=\left(8.78 \times 10^{2} \pm 4.54 \times\right. \\
\left.10^{1}\right) x\end{array}$ & $0.96(16.0)$ & 2.91 \\
\hline Enniatin B & 639.83 & 29.94 & $640.3[\mathrm{M}+\mathrm{H}]^{+}$ & 120 & 95 & $\begin{array}{l}y=\left(3.50 \times 10^{2} \pm 1.07 \times\right. \\
\left.10^{1}\right) x\end{array}$ & $1.16(19.2)$ & 3.50 \\
\hline Enniatin $B_{1}$ & 653.86 & 30.98 & $654.3[\mathrm{M}+\mathrm{H}]^{+}$ & 120 & 95 & $\begin{array}{l}y=\left(2.00 \times 10^{3} \pm 2.01 \times\right. \\
\left.10^{2}\right) x\end{array}$ & $0.11(1.8)$ & 0.34 \\
\hline Fumonisin $B_{1}$ & 721.84 & 18.88 & $723.2[\mathrm{M}+2 \mathrm{H}]^{+}$ & 100 & 34 & $\begin{array}{l}y=\left(1.19 \times 10^{3} \pm 1.27 \times\right. \\
\left.10^{2}\right) x\end{array}$ & $0.08(1.3)$ & 0.24 \\
\hline Fumonisin $B_{2}$ & 705.84 & 20.09 & $706.2[\mathrm{M}+\mathrm{H}]^{+}$ & 100 & 34 & $\begin{array}{l}y=\left(3.20 \times 10^{2} \pm 3.23 \times\right. \\
\left.10^{1}\right) x\end{array}$ & $0.43(7.17)$ & 1.30 \\
\hline
\end{tabular}


Table 1 Performance parameters and mass detector settings for the assessed analytes in order of increasing molar mass (Continued)

\begin{tabular}{|c|c|c|c|c|c|c|c|c|}
\hline Analyte & $\begin{array}{l}\text { Molar mass, } \\
\mathrm{g} / \mathrm{mol}\end{array}$ & $\begin{array}{l}\text { Retention } \\
\text { time, min }\end{array}$ & Target ion, m/z & Fragmentor & $\begin{array}{l}\text { Dwell time, } \\
\text { ms }\end{array}$ & $\begin{array}{l}\text { Calibration curve } \\
\text { equation }{ }^{a} \text { or } \\
\text { response factor }\end{array}$ & $\begin{array}{l}\text { b Limit of } \\
\text { detection, } \mu \mathrm{g} \\
\mathrm{kg}^{-1}\left({ }^{C} \mu \mathrm{L}^{-1}\right)\end{array}$ & $\begin{array}{l}\text { Limit of } \\
\text { quantification } \\
\mu \mathrm{g} \mathrm{kg}^{-1}\end{array}$ \\
\hline \multicolumn{9}{|l|}{ Veterinary residues } \\
\hline Sulfamethazine & 278.33 & 9.18 & $279.0[\mathrm{M}+\mathrm{H}]^{+}$ & 120 & 146 & $2.61 \times 10^{4} \pm 6.91 \times 10^{3}$ & $45.45(50)$ & 151.52 \\
\hline Spectinomycin & 332.35 & 1.18 & $333.1[\mathrm{M}+\mathrm{H}]^{+}$ & 140 & 97 & $7.53 \times 10^{2} \pm 1.91 \times 10^{1}$ & $68.18(75)$ & 227.27 \\
\hline Florfenicol & 358.20 & 13.15 & $\begin{array}{c}339.9 \\
{\left[\mathrm{C}_{12} \mathrm{H}_{14} \mathrm{Cl}_{2} \mathrm{NO}_{4} \mathrm{~S}\right]^{+\cdot}-\mathrm{F} \cdot}\end{array}$ & 120 & 97 & $1.33 \times 10^{2} \pm 2.32 \times 10^{1}$ & $45.45(50)$ & 151.52 \\
\hline Cloramphenicol & 323.13 & 14.51 & $344.9[\mathrm{M}+\mathrm{Na}]^{+}$ & 120 & 97 & $3.02 \times 10^{2} \pm 9.11 \times 10^{1}$ & $46.36(51)$ & 154.55 \\
\hline Penicillin G & 334.39 & 17.28 & $\begin{array}{c}354.0[\mathrm{M}+\mathrm{Na}]^{+} \text {and } \\
367.0\left[\mathrm{M}+2 \mathrm{H}_{2} \mathrm{O}\right]^{+}\end{array}$ & 60 & 83 & $1.75 \times 10^{3} \pm 2.67 \times 10^{2}$ & $97.27(107)$ & 324.24 \\
\hline Lincomycin & 406.54 & 7.23 & $407.1[\mathrm{M}+\mathrm{H}]^{+}$ & 120 & 146 & $4.32 \times 10^{3} \pm 1.41 \times 10^{2}$ & $81.82(90)$ & 272.73 \\
\hline $\begin{array}{l}\text { 4- } \\
\text { epianhydrotetracycline }\end{array}$ & 426.42 & 14.77 & $427.0[\mathrm{M}+\mathrm{H}]^{+}$ & 120 & 97 & $1.27 \times 10^{3} \pm 5.44 \times 10^{2}$ & $100.01(105)$ & 303.03 \\
\hline Methacycline & 442.42 & 13.68 & $443.0[\mathrm{M}+\mathrm{H}]^{+}$ & 120 & 97 & $2.33 \times 10^{2} \pm 7.83 \times 10^{1}$ & $57.27(63)$ & 190.91 \\
\hline Tetracycline & 444.44 & 10.12 & $445.0[\mathrm{M}+\mathrm{H}]^{+}$ & 120 & 97 & $2.00 \times 10^{3} \pm 4.23 \times 10^{2}$ & $41.82(46)$ & 139.39 \\
\hline Doxycycline & 444.44 & 14.08 & $446.0[\mathrm{M}+2 \mathrm{H}]^{+}$ & 120 & 97 & $1.17 \times 10^{2} \pm 5.67 \times 10^{1}$ & $83.64(92)$ & 278.79 \\
\hline 4-epitetracycline & 444.44 & 10.23 & $447.1[\mathrm{M}+3 \mathrm{H}]^{+}$ & 140 & 97 & $3.19 \times 10^{2} \pm 3.23 \times 10^{1}$ & $90.91(100)$ & 275.48 \\
\hline Minocycline & 457.48 & 7.14 & $458.1[\mathrm{M}+\mathrm{H}]^{+}$ & 120 & 146 & $1.25 \times 10^{3} \pm 1.01 \times 10^{2}$ & 71.21 (83) & 254.38 \\
\hline Demeclocycline & 464.85 & 11.43 & $465.0[\mathrm{M}+\mathrm{H}]^{+}$ & 120 & 97 & $1.12 \times 10^{3} \pm 7.34 \times 10^{2}$ & $41.82(46)$ & 139.39 \\
\hline Oxytetracycline & 460.44 & 9.46 & $461.0[\mathrm{M}+\mathrm{H}]^{+}$ & 140 & 97 & $2.27 \times 10^{2} \pm 6.51 \times 10^{1}$ & $82.73(91)$ & 275.76 \\
\hline 4-epioxytetracycline & 460.44 & 9.42 & $462.3[\mathrm{M}+2 \mathrm{H}]^{+}$ & 120 & 146 & $2.94 \times 10^{2} \pm 2.21 \times 10^{1}$ & $101.02(113)$ & 368.63 \\
\hline Chlortetracycline & 478.88 & 13.10 & $479.0[\mathrm{M}+\mathrm{H}]^{+}$ & 120 & 97 & $1.25 \times 10^{3} \pm 5.55 \times 10^{2}$ & $92.12(102)$ & 301.06 \\
\hline 4-epichlortetracycline & 478.88 & 11.57 & $479.1[\mathrm{M}+\mathrm{H}]^{+}$ & 120 & 97 & $6.51 \times 10^{2} \pm 3.48 \times 10^{1}$ & $132.73(146)$ & 442.42 \\
\hline Virginimycin $M_{1}$ & 525.60 & 21.94 & $526.1[\mathrm{M}+\mathrm{H}]^{+}$ & 120 & 83 & $4.46 \times 10^{3} \pm 2.46 \times 10^{2}$ & $59.09(65)$ & 196.97 \\
\hline Monensin A & 670.88 & 24.56 & $693.2[\mathrm{M}+\mathrm{Na}]^{+}$ & 180 & 83 & $1.13 \times 10^{4} \pm 1.01 \times 10^{3}$ & $40.91(45)$ & 136.36 \\
\hline Erythromycin & 733.94 & 16.83 & $734.3[\mathrm{M}+\mathrm{H}]^{+}$ & 140 & 83 & $1.16 \times 10^{4} \pm 1.76 \times 10^{3}$ & $80.93(89)$ & 264.56 \\
\hline Narasin & 765.04 & 25.20 & $787.3[\mathrm{M}+\mathrm{Na}]^{+}$ & 260 & 83 & $1.26 \times 10^{3} \pm 2.26 \times 10^{2}$ & $24.55(27)$ & 81.82 \\
\hline Virginimycin $S_{1}$ & 823.90 & 23.35 & $824.1[\mathrm{M}+\mathrm{H}]^{+}$ & 120 & 83 & $3.47 \times 10^{3} \pm 3.44 \times 10^{2}$ & $59.09(65)$ & 196.97 \\
\hline Tylosin & 916.11 & 18.05 & $916.2[\mathrm{M}+]$ & 140 & 83 & $5.37 \times 10^{3} \pm 2.88 \times 10^{2}$ & $45.45(48)$ & 151.52 \\
\hline
\end{tabular}

${ }^{a}$ All trend line intercepts adjusted to zero as their values are deemed negligible with respect to the slopes and areas. The equations shown are the result of an average of three curves measured independently and under reproducibility conditions

${ }^{b}$ Limit of detection and quantification calculated as $\mathrm{S} / \mathrm{N}$ ratio times 3.3 and 10 , respectively. Values corroborated by extinction assays

'Smallest concentration detected for each analyte within the calibration curve (experimental data)

washed with $2 \mathrm{~mL} \mathrm{MeOH} / \mathrm{H}_{2} \mathrm{O}$ (5:95) and $2 \mathrm{~mL}$ of $\mathrm{MeOH}$ was used to elute analytes. Eluates were concentrated to dryness under vacuum at $60^{\circ} \mathrm{C}$ (Centrivap, LABCONCO, Kansas City, MO, USA), reconstituted with $300 \mu \mathrm{l}$ of $\mathrm{MeOH}$, and transferred to an HPLC vials with polypropylene inserts (5182-0549, Agilent Technologies, Santa Clara, CA, USA).

\section{Antimicrobial drugs}

Extraction of antibiotics was performed based on a published protocol (Duelge et al. 2017). Briefly, $5.0 \mathrm{~g}$ from each sample were mixed into a $50 \mathrm{~mL}$ polypropylene centrifuge tube with $50 \mu \mathrm{L}$ of a $400 \mu \mathrm{g} \mathrm{mL}$ internal standard mix composed of ciprofloxacin- $\mathrm{d}_{8}$ (for fluoroquinolones, sulfonamides and tetracyclines) and flunixin- $\mathrm{d}_{3}$ (for macrolides and $\beta$-lactams). This mixture was resuspended with $5 \mathrm{~mL}$ acetate buffer ( $1 \mathrm{~mol} \mathrm{~L}^{-1}$, pH 5.0), $10 \mathrm{~mL} \mathrm{ACN}$ and $10 \mathrm{~mL} \mathrm{MeOH}$ and the resulting suspension was homogenized for $2 \mathrm{~min}$ at $18000 \mathrm{rpm}$ using an Ultra-turrax ${ }^{\circ}$ homogenizer. Debris and suspended solids were removed by centrifugation at $5000 \mathrm{~g}$ for $10 \mathrm{~min}$ (Thermo Scientific Sorvall $^{\text {is }}$ ST 16R, Waltham, MA, USA) and supernatants were transferred to $50 \mathrm{~mL}$ volumetric flasks. The sample was re-extracted with $5 \mathrm{~mL}$ of acetonitrile and $5 \mathrm{~mL}$ of methanol, dispersed for an additional minute and centrifuged for another $10 \mathrm{~min}$. Both supernatants were combined in the flask and the $50 \mathrm{~mL}$ volume was made up with water. A 4-fold dilution with water was performed to reduce organic solvent fraction. An Oasis ${ }^{\circ}$ HLB SPE cartridge was placed on a 12-port vacuum manifold and conditioned with $2 \mathrm{~mL} \mathrm{ACN}$ followed by $2 \mathrm{~mL}$ water. A 10 $\mathrm{mL}$ sample aliquot was loaded onto the reservoir and 
allowed to pass through the column at the rate of $1 \mathrm{~mL}$ $\min ^{-1}$. After drying for $5 \mathrm{~min}$ under vacuum $(\sim 10$ in $\mathrm{Hg})$, the column was washed with $2 \mathrm{~mL}$ water and $2 \mathrm{~mL}$ of $\mathrm{MeOH}$ and dried again for $5 \mathrm{~min}$ under vacuum. Analytes were eluted with $1 \mathrm{~mL}$ of 50:50 MeOH:ACN into a $2 \mathrm{~mL}$ HPLC vial.

\section{LC equipment and analysis conditions}

All assays were performed using an Agilent Technologies LC/MS system equipped with a 1260 infinity quaternary pump (61311C), a column compartment (G1316A), an automatic liquid sampler module (ALS, G7129A) and a 6120-single quadrupole mass spectrometer with electrospray ionization ion source (Agilent Technologies, Santa Clara, CA, USA).

\section{Mycotoxin contaminant analysis}

The gradient analysis was performed at $0.15 \mathrm{~mL} \mathrm{~min}^{-}$ ${ }^{1}$ using as solvents $\mathrm{A} A C N$ and $\mathrm{B}_{2} \mathrm{O}$, both acidified with FA at $0.1 \mathrm{~mL} / 100 \mathrm{~mL}$. The gradient was set as follows: at $0 \mathrm{~min} 10 \% \mathrm{~A}$, at $4 \mathrm{~min} 10 \% \mathrm{~A}$, at $22 \mathrm{~min}$ $100 \% \mathrm{~A}$, at $25 \mathrm{~min} 10 \% \mathrm{~A}$ and finally at $35 \mathrm{~min} 10 \%$ A, obtaining a complete chromatographic separation for 26 toxins (Fig. 1a). A volume of $10 \mu \mathrm{L}$ was injected into the system. Column compartment was kept at $40{ }^{\circ} \mathrm{C}$ during analysis.

\section{Antimicrobial residue analysis}

The gradient analysis was performed at $0.8 \mathrm{~mL} \mathrm{~min}^{-1}$ using as solvents $\mathrm{A} \mathrm{ACN}, \mathrm{B} \mathrm{MeOH}$, and $\mathrm{C}$ water, all acidified with FA at $0.1 \mathrm{~mL} / 100 \mathrm{~mL}$. Gradient was set as follows: at $0 \mathrm{~min} 100 \% \mathrm{C}$, at $20 \mathrm{~min} 35 \% \mathrm{~A}$ and $65 \% \mathrm{C}$, at $23 \mathrm{~min} 95 \% \mathrm{~B}$ and $5 \% \mathrm{C}$, at $24 \mathrm{~min} 95 \% \mathrm{~B}$ and $5 \% \mathrm{C}$, at $28 \mathrm{~min} 95 \% \mathrm{~B}$ and $5 \% \mathrm{C}$, at $29 \mathrm{~min}$ $100 \% \mathrm{C}$ and finally at $38 \mathrm{~min} 100 \% \mathrm{C}$, obtaining a complete chromatographic separation for 23 antibiotics (Fig. 1b). A volume of $1 \mu \mathrm{L}$ was injected into the system. Column compartment was kept at $20^{\circ} \mathrm{C}$ during analysis.

\section{Chromatographic column and MS detection}

Considering the variability in structures, functional groups, and chemical moieties of the target analytes, a reverse phase $\mathrm{C}_{18}$-based chromatographic column (Zorbax Eclipse Plus, $3.0 \mathrm{~mm}$ ID $\times 100 \mathrm{~mm}, 3.5 \mu \mathrm{m}, \mathrm{P} /$ N 959961-302, Agilent Technologies, Santa Clara, CA, USA) was used for analytical separation. For each analyte, the cone electrical energy was cycled (i.e., from 20 to $280 \mathrm{~V}$ ) to determine the voltage that yielded the highest sensitivity (Table 1). Drying gas, nebulizer pressure, drying gas temperature and capillary voltage was set, respectively, to $10.0 \mathrm{~L} \mathrm{~min}^{-1}, 50$ psi, $350{ }^{\circ} \mathrm{C}$, and $4000 \mathrm{~V}$ for positive ion mode electrospray ionization $\left(\mathrm{ESI}^{+}\right)$. Total ion chromatographs (scan mode: mass range, cone voltage and detector gain set to $50-750 \mathrm{~m} / \mathrm{z}$ for mycotoxins or $50-1000 \mathrm{~m} /$ $\mathrm{z}$ for antibiotics, $120 \mathrm{~V}$ and 10.0 , respectively) of individual standards were used for choosing the ion that would later be used for selected ion monitoring (SIM mode, peak width and cycle time set to $0.1 \mathrm{~min}$, and $0.60 \mathrm{~s} \mathrm{cycle}^{-1}$ ). The molar mass, target ions, retention times, cone voltage, and obtained limits of detection and quantification of each analyte are presented in Table 1. During MS molecular ion analysis, signals to be monitored were clustered into time programmed SIM groups to minimize the number of ions acquired at any one time (Table 1 and Fig. 1a, b).

\section{Method validation}

Method validation was performed according to US FDA (2015) and ICH (Borman and Elder, 2018) validation criteria. Quality assurance materials, both for mycotoxin and antimicrobial assays, were tested several times under reproducibility conditions (see footnote for Table 2). Standard deviation certified by the manufacturer or calculated $z$ values were used as method performance parameters. Acceptable $z$ values (i.e., from -2 to 2 ) were considered as proof of the method acceptable bias, accuracy, and recovery. In this scenario, $z$ values indicate the number of standard deviations from the mean a data point is. Mathematically, $z=(x-\mu) / \sigma$. Then, $\mathrm{z}$ values are calculated as follows: robust mean concentration (obtained from the method/analyte performance agreed among several laboratories) subtracted by the result obtained by the laboratory divided by the robust standard deviation. To assess intraday repeatability, $n=3$ reference materials were extracted and quantified by the same analyst, equipment, and environmental conditions. As an additional quality parameter, reproducibility data must coincide with HorRat values (i.e., ranging from $0.3 \leq x \leq$ 1) and predicted values within those expected by Horwitz Trumpet function (Horwitz and Albert 2006; Thomson 2007). A certified sample devoid of any of the analytes of interest; equine, cat and beef non-medicated and mycotoxin feed blanks were obtained (i.e., AAFCO check samples 2018-21, 2018-25, 2018-28). Blank samples and additional solvent blanks were used as chromatographic backgrounds during quantification to remove artifacts, if present. Limits of detection and limits of quantification were assayed using the resulting signal-to-noise ratio obtained from blank matrices. Theoretical limits were assessed by measuring the signal to noise ratio and multiplying it by 3.3 or 10 , respectively. Additionally, each compound was verified experimentally, using a dilution-to-extinction method. As a simple precision component, retention times shifts were also studied 


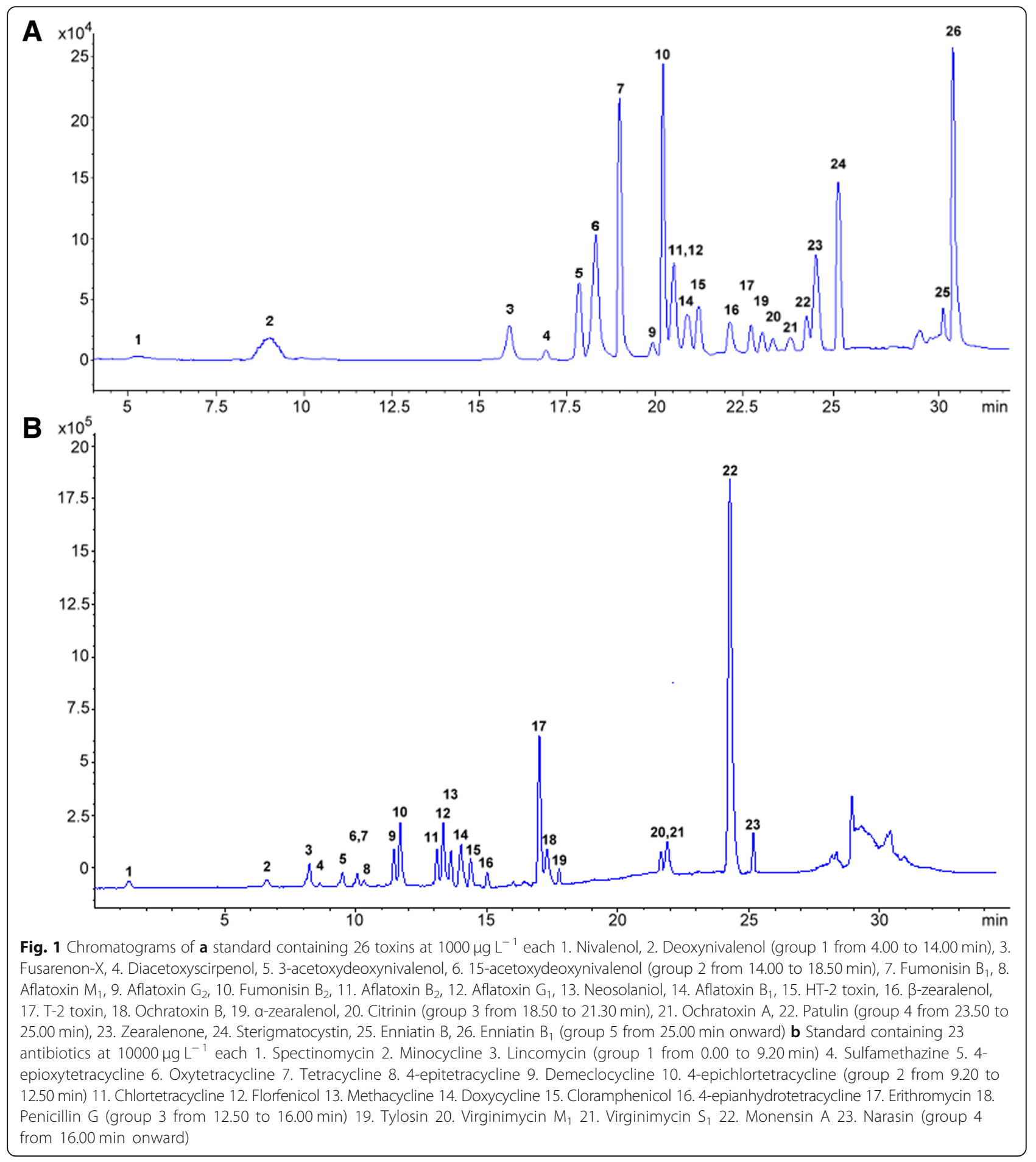

using another batch of the same chromatographic column (SN USUXR16343), shifts \pm 0.2 min were considered acceptable.

\section{Statistical analysis}

Calibration curves parameters (i.e., slopes and intercepts), coefficients of determination, limits of detection, and standard errors were computed as a linear fit model using SAS JMP 13 (Marlow, Buckinghamshire, England). Spearman rank order test was used to determine association with sampling date and toxin levels; variables with positive correlation coefficients and $p<0.050$ tend to increase together (Sigma Plot 14.0 Systat Software, Inc., San Jose, CA, USA). 
Table 2 Analytical performance of the proposed method for detection and quantification of mycotoxins and antibiotics in animal feed

\begin{tabular}{|c|c|c|c|c|c|c|c|c|}
\hline \multicolumn{9}{|c|}{ Mycotoxins } \\
\hline \multirow{4}{*}{ Analyte } & \multicolumn{4}{|c|}{ Theoretical } & \multicolumn{4}{|c|}{ Experimental } \\
\hline & $\begin{array}{l}\text { Reporte } \\
\quad d \\
\text { average }\end{array}$ & \multicolumn{3}{|c|}{ Acceptance range } & $\begin{array}{l}\text { Experimental } \\
\quad \text { data }\end{array}$ & $\begin{array}{l}\text { Intraday } \\
\text { repeatibilit } \\
y, \% R S D\end{array}$ & $\begin{array}{c}\text { Reproducib } \\
\text { ility, \%RSD } \\
\text { (Predicted }^{c} \\
\text { ) }\end{array}$ & $\begin{array}{c}\text { Absolute } \\
\text { uncertainty, } \\
U_{x} \text { (relative } \\
\text { uncertainty, } \\
\left.U_{x / x}\right), \mu g \mathrm{~kg}^{-1}\end{array}$ \\
\hline & \multirow{2}{*}{\multicolumn{5}{|c|}{$\begin{array}{c}2 \mathrm{SD} \\
\text { Concentration, } \mu \mathrm{g} \mathrm{kg} \mathrm{kg}^{-1}\end{array}$}} & \multirow{4}{*}{\multicolumn{2}{|c|}{$\begin{array}{c}8.34 \\
(12.67) \\
12.33 \\
(15.12)\end{array}$}} & \multirow[b]{3}{*}{1229} \\
\hline & & & & & & & & \\
\hline Fumonisin $\mathrm{B}_{1}^{b}$ & 4300 & \multirow[b]{2}{*}{$5400-6600$} & \multirow[b]{2}{*}{$4900-7100$} & \multirow[b]{2}{*}{$4300-7700$} & $4710 \pm 580$ & & & \\
\hline Fumonisin $\mathrm{B}_{2}{ }^{b}$ & 1400 & & & & $1450 \pm 180$ & & & 13.34 \\
\hline Zearalenone & 226.3 & $208.2-244.4$ & $190.1-262.5$ & $172.0-280.6$ & $204.44 \pm 24.98$ & 6.73 & $\begin{array}{l}13.46 \\
(20.32)\end{array}$ & 18.11 \\
\hline Ochratoxin A & 62.1 & $44.3-80.0$ & $26.4-97.9$ & $8.5-115.7$ & $71.39 \pm 8.72$ & 6.01 & $\begin{array}{l}17.49 \\
(20.80) \\
\end{array}$ & 15.98 \\
\hline \multicolumn{9}{|c|}{ Antibiotics } \\
\hline \multirow[t]{2}{*}{ Analyte } & $\begin{array}{l}\text { Robust } \\
\text { mean }\end{array}$ & $\begin{array}{l}\text { Robust } \\
\text { Standard } \\
\text { deviation }\end{array}$ & $\begin{array}{l}\text { Experimental } \\
\quad \text { data }\end{array}$ & $\begin{array}{l}\text { Experimental } \\
\text { z value }\end{array}$ & $\begin{array}{l}\text { Intraday } \\
\text { repeatibility, } \\
\% R S D\end{array}$ & \multicolumn{2}{|c|}{$\begin{array}{c}\text { Repoducibility, } \\
\% \text { RSD } \\
\text { (Predicted }^{c} \text { ) }\end{array}$} & $\begin{array}{c}\text { Absolute } \\
\text { uncertainty, } U_{x} \\
\text { (relative } \\
\text { uncertainty, } U_{x / x} \text { ), } \\
\mu g \mathrm{~kg}^{-1}\end{array}$ \\
\hline & \multicolumn{4}{|c|}{ Concentration, $\mathrm{mg} \mathrm{kg}^{-1}$} & & & & \\
\hline Chlortetracycline & 254.10 & 13.24 & $\begin{array}{c}252.29 \pm \\
72.33\end{array}$ & -0.13 & 4.05 & \multicolumn{2}{|c|}{$4.56(6.93)$} & 7.65 \\
\hline Monensin & 2.06 & 0.65 & $2.23 \pm 0.44$ & 0.26 & 1.97 & \multicolumn{2}{|c|}{$9.87(14.18)$} & 5.76 \\
\hline
\end{tabular}

${ }^{a}$ Average concentration values obtained from $n=18$ and $n=8$ independent measurements for mycotoxin and antibiotic reference material, respectively. Used as measurement for bias, accuracy, and veracity

${ }^{\mathrm{b}}$ The manufacturer of the certified material provides the acceptance values for fumonisin as the sum of both fractions i.e., $B_{1}+B_{2}$

${ }^{c}$ Predicted $\mathrm{RSD}_{R} \%$ calculated according to Horwitz $2^{(1-0.5 \log C)}$ (Hall and Selinger 1989)

\section{Results and discussion \\ Method validation \\ Mycotoxin analysis}

Dynamic, working, and linear ranges were established at 1.15 to $1.25 \times 10^{-2}, 1.00$ to $6.25 \times 10^{-2}$, and $7.14 \times 10^{-1}$ to $4.46 \times 10^{-2} \mathrm{mg} \mathrm{L}^{-1}$, respectively. Linearity was assessed as average of multiple calibration curves measured under reproducibility conditions. Regarding accuracy, bias, and reliability, our method only differed from those declared by the manufacturer by one standard deviation (Table 2). In this case, the calculated uncertainty ranged from 12.29 to $18.11 \%$ of the reported values. Reproducibility, expressed as relative standard deviations, ranged from 8.34 to $17.49 \%$. No interferences were observed from 0 to $25 \mathrm{~min}$ (Fig. 2a). On the other hand, several non-specific signals arise from 25 to $30 \mathrm{~min}$ region even on blank matrix samples, which makes ennantin congener identification relatively more complex, though this does not hinders sensitivity for these mycotoxins (Table 1 and Fig. 2a). An unidentified signal with a 20.44 min retention time accompanied all samples in which fumonisin fractions were found. Background subtraction aid to simplify the integration and quantification steps. Based on its mass spectra and retention time comparison using an analytical standard, this signal was identified as fumonisin $\mathrm{B}_{3}$ (experimental ion obtained $[\mathrm{M}+\mathrm{H}]^{+} 706.2 \mathrm{~m} / \mathrm{z}$ while fumonisin $\mathrm{B}_{3}$ has a molar mass of $705.839 \mathrm{~g} \mathrm{~mol}^{-1}$ ). Detector gain for all mycotoxins set at 10, except deoxynivalenol and nivalenol set at 15 .

\section{Antimicrobial analysis}

Limits of detection were established between 24.55 and $132.73 \mu \mathrm{g} \mathrm{kg}^{-1}$. Average $\mathrm{z}$ values of -0.13 and 0.26 were determined for monensin and chlortetracycline, respectively, indicating excellent accuracy and veracity (Table 2). Acceptable bias is also attained when the experimental data is compared to a known concentration (Table 2). The measured relative uncertainty ranged between 5.76 to $7.65 \%$ of the reported values. No injection-injection carryover was observed. Reproducibility values are within recommended values (Table 2). In the region where monensin and narasin elute some matrix interferences are observed; however, limits of detection are still relatively low and identification can be performed effortlessly (Fig. 2b). Target ions selected for each compound (see for example Fig. 3a, b) and selection of molecular ion is performed after pure standard complete mass spectra is obtained (see for example Fig. 3b, d). Interferences are screened considerably in SIM mode. Analysis of a $20 \mathrm{~g}$ monensin/100 g feed quality standard with our method indicated a concentration of $(17.04 \pm 0.98)$ $\mathrm{g} / 100 \mathrm{~g}$ (Table 3). As our method is performed at $20^{\circ} \mathrm{C}$, retention times are susceptible to room temperature shifts. We observed $0.5 \mathrm{~min}$ retention time swings if room temperature was raised $2{ }^{\circ} \mathrm{C}$ (from 20 to $22^{\circ} \mathrm{C}$ ). Detector gain for all antimicrobials was set at 1 . 


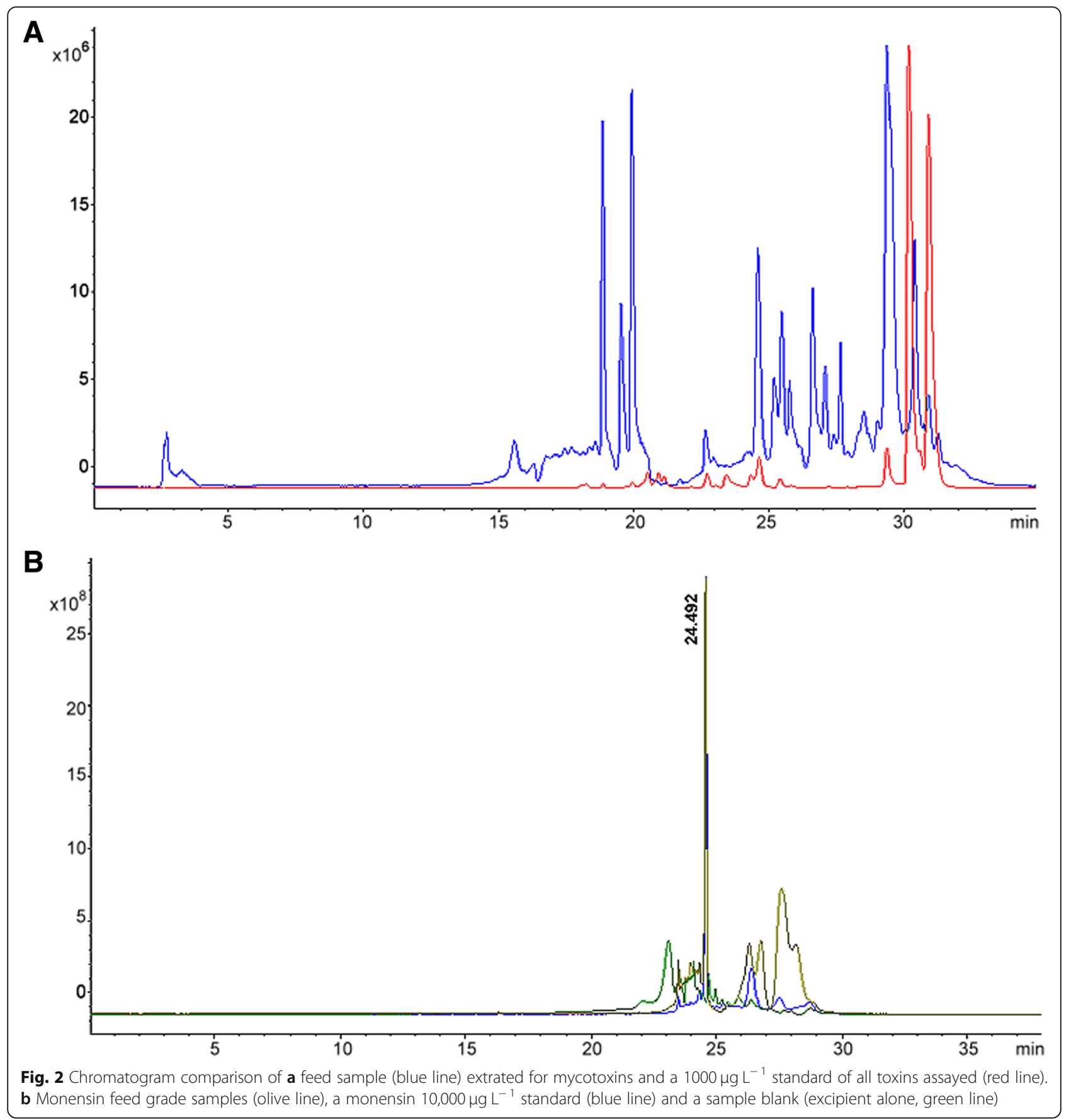

\section{Method application for mycotoxins in feed Overall mycotoxin prevalence}

In relative terms, among the assayed toxins, fumonisin contamination was the most frequent. Fumonisin fraction $B_{1}$ and $B_{2}$, exhibited prevalences of 49.76 and $53.66 \%$, respectively; Table 4 . Maximum concentrations reached 4554.36 and $8646.67 \mu \mathrm{g} \mathrm{kg}^{-1}$ for $\mathrm{FB}_{1}$ and $\mathrm{FB}_{2}$, respectively (Table 4). However, with the exception of the two above-mentioned toxins, the rest of the toxins presented relatively low prevalence, as the majority of the toxins resulted below the method's limit of detection (i.e.,; from $n=170 / 205$ to $n=203 / 205$ ) (Table 4). Less frequent toxins include fusarenone-X, patulin, $\beta$-zearalenol, neosolaniol, ochratoxin $\mathrm{B}$, sterigmatocystin, diacetoxyscirpenol, and citrinin, which were found in $n=2 / 205$ (0.98\%), $n=2 / 205$ (0.98\%), $n=3 / 205$ (1.46\%), $n=4 / 205$ (1.95\%), $n=6 / 205$ (2.93\%), $n=6 / 205$ (2.93\%), $n=7 / 205$ (3.41\%) and $n=8 / 205$ (3.90\%) samples. The presence of sterigmatocystin in some samples should be an indicative of Aspergillus spp. metabolism [serves as a late 
intermediate in aflatoxin biosynthesis (Viegas et al. 2018; Díaz-Nieto et al. 2018)]. Patulin was found in a dairy cattle samples, which may be related to the inclusion within these feed formulations of citrus pulps (Zbyňovská et al. 2016); this toxin is usually related to fruits. Toxicologically relevant concentrations of toxin metabolites, including HT-2 (6.38-303.22 $\left.\mathrm{g} \mathrm{kg}^{-1}\right), \quad 3$-acetoxydeoxynivalenol $\left(1.88-3236.56 \mu \mathrm{g} \mathrm{kg}^{-1}\right)$, were found. By contrast, deoxynivalenol/15-acetoxydeoxynivalenol (15.06-364.10/1.74$355.60 \mu \mathrm{g} \mathrm{kg}^{-1}$ ) concentrations were relatively low. Diacetoxyscirpenol is a trichothecene mycotoxin produced by a Fusarium mold found in temperate regions (Sospedra et al. 2010), said toxin was found in soybean meal and corn meal samples which are imported from countries such as the USA. Deoxynivalenol has been reported previously in marine animal feeds (Pietsch et al. 2013), though our data only found 3-acetyldeoxynivalenol, its incidence indicates that an original high concentration of deoxynivalenol was once present. Deoxynivalenol metabolites exhibit higher than the parent compounds, and co-occurrence of the latter and its acetylated relatives have been reported (Payros et al. 2016). Considerable concentrations of $\alpha / \beta$-zearalenol $\left(0.25-920.65 / 228.03-1900.62 \mu \mathrm{g} \mathrm{kg}^{-1}\right)$ were also found. On another hand, enniatin B was also relatively prevalent (15.12\%) and exhibited levels of $143.11-3566.81 \mu \mathrm{g} \mathrm{kg}^{-1}$. Interestingly, for the case of aflatoxins, the $\mathrm{AFG}_{2}$ fraction was found to be the most frequent among the samples tested samples $12.68 \%(n=26 / 205)$ (Table 4$)$. Maximum concentrations reach for aflatoxin are $22.39\left(\mathrm{AFB}_{2}\right)$ and 21.84 $\left(\mathrm{AFG}_{2}\right) \mu \mathrm{g} \mathrm{kg}^{-1}$ (Table 4). Animal feed contaminated with mycotoxins can negatively impact health, productiveness and general well-being of the animal additionally, carry-over to other food matrices [e.g., milk (Fink-Gremmels 2008) and eggs (Lee et al. 2016)] is a real concern. Of special concern is aflatoxin prevalence in feeds as they are recognized as cytotoxic, teratogenic, and immunotoxic (Granados-Chinchilla et al. 2017).

\section{Mycotoxin prevalence by feedstuff and legislative thresholds}

From the feed ingredients examined, soybean and corn meal had the highest prevalence for deoxynivalenol $(42.86 \%)$ and fumonisin $B_{2} \quad(25.00 \%)$, respectively (Table 5). When arranged by feed type, all feeds contaminated with fumonisin exhibited similar prevalence (i.e., 19.89-37.50\%) (Table 5). Fumonisins, though found with the higher concentrations and frequency, are the toxins with laxer legislation or guideline values, except the case of for pigs which are set to $5000 \mathrm{mg} \mathrm{kg}^{-1}$. Fumonisins have demonstrated particular toxicity toward pigs (prevalence of $25.43 \%$ for both $\mathrm{FB}_{1}$ and $\mathrm{FB}_{2}$, Burel et al. 2013; Schertz et al. 2018). Though, higher fumonisin prevalence was found in poultry feed and pet food. Toxins found herein in dry extruded pet food have been

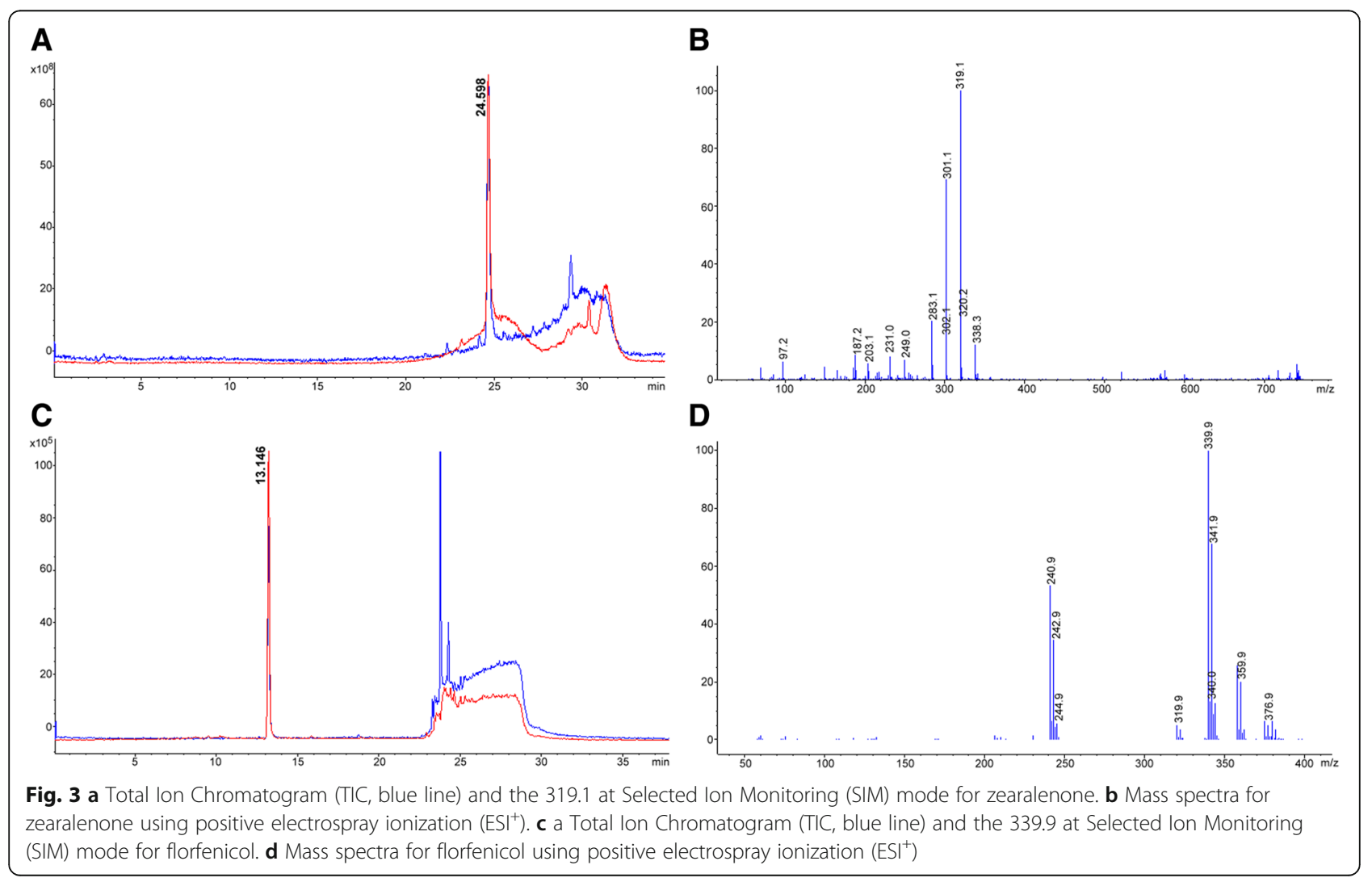


Table 3 Evaluation of commercial monensin standards used routinely in feed mills

\begin{tabular}{lccc}
\hline Sample & Guaranteed analysis, $\mathrm{g} / 100 \mathrm{~g}$ & Experimental result ${ }^{\mathrm{a}}$, Concentration $\pm \mathrm{U}_{\mathrm{x}} / \mathrm{x} \mathrm{g} / 100 \mathrm{~g}$ & Variation, $\mathrm{g} / 100 \mathrm{~g}\left(\mathrm{percentile} \mathrm{b}^{\mathrm{b}}\right)$ \\
\hline 1 & 20 & $17.04 \pm 0.98$ & $-2.96(14.8)$ \\
2 & 20 & $22.26 \pm 1.28$ & $2.26(11.3)$ \\
3 & 7 & $8.39 \pm 0.48$ & $1.39(19.9)$ \\
4 & 0.2 & $0.15 \pm 0.04$ & $-0.05(21.1)$ \\
\hline
\end{tabular}

${ }^{\mathrm{a}}$ Monensin standard (M5273 lot $\left.117 \mathrm{~K} 5006\right)$ used for quantification, $91 \%$ purity as reported by the manufacturer. Work solution concentration, ca. 10 mg L ${ }^{-1}$

${ }^{\mathrm{b}}$ Calculated as the subtraction between the experimental value and guaranteed value divided by the guaranteed value

reported previously (Gazzotti et al. 2015). Citrin was found in pet food which is relevant since dogs are very susceptible to this molecule (EFSA 2012). Companion animal exposure to mycotoxin through feed is especially worrisome due to their closeness to humans. Ochratoxin A exceeded recommendations (i.e., $>50 \mu \mathrm{g} \mathrm{kg}^{-1}$ ) in pig and sow feeds with $n=11$ samples in this condition (Table 5). Ochratoxin group mycotoxins have been reported to be linked to serious animal diseases including poultry ochratoxicosis, and porcine nephropathy (Heussner and Bingle 2015). Overall, beef cattle, swine and dairy cattle feeds showed the most number of incidents with $n=51,54$, and 186 samples with some degree of mycotoxin contamination. Dairy cattle and swine feeds included the higher number of samples exceeding guideline values ( $n=3$ with zearalenone and $n=5$ with zearalenone $(n=2)$, fumonisin $\mathrm{B}_{2}(n=1)$, ochratoxin $\mathrm{A}(n=$ $1)$, and aflatoxin $G_{1}(n=1)$, respectively, Table 5). Interestingly, the two samples exceeded the $20 \mu \mathrm{g} \mathrm{kg}^{-1}$ total aflatoxin legal threshold defined by the European Commission with just one fraction (Table 5). Enniantin B were found in significant concentrations in several matrices (up to $711.74,914.05,1115.50$, and $2595.64 \mu \mathrm{g}$ $\mathrm{kg}^{-1}$ in calf, dairy cattle, beef cattle, and swine feeds, respectively) (Table 5). Overall, few samples exceeded threshold concentrations defined in current guidelines. Though legal bounds are set considering only one contaminant, synergy due to mycotoxin co-occurrence is to be considered (Streit et al. 2012; Alassane-Kpembi et al. 2017); this is possible through multi-toxin methods such as the one presented here (Malachová et al. 2017).

\section{Mycotoxin co-occurrence}

Using the toxin profile suggested here, toxin co-occurrence seems to be a fairly common event ( $n=123$ samples presenting $2^{+}$toxins) (Table 6 ). Counterintuitively, finding 4 toxins in a feed seems to be more common $(n=34)$ followed by $5,1,2$, and 3 with $n=28,27,25$, and 24, respectively (Table 6). The diversity of mycotoxins found is higher in two specific groups of feed; with $n=20$ (dairy cattle) and $n=13$ (in swine feed) different analytes identified overall (Table 6). Also, dairy cattle was found to be the matrix most contaminated with multiple toxin simultaneously (i.e., up to 9 different toxins) (Table 6). The most common events of co-occurrence for samples with $n=2$ toxins occurring simultaneously were $\mathrm{FB}_{1}+\mathrm{FB}_{2}(n=14 / 25$, $56.00 \%)$ and $\mathrm{FB}_{2}+\mathrm{AFG}_{2}(n=5 / 25,20.00 \%)$ (Table 6). Additive cytotoxic effects have already been reported in the presence of two or more mycotoxins (Fernandez-Blanco et al. 2018; Zhou et al. 2017). Similarly enniatin B has demonstrated adverse effects and changes in gene expression over different cell lines (Jonsson et al. 2016; Manyes et al. 2018). Along with toxins such as trichothecenes, fumonisins, and zearalenone are among the battery of metabolites biosynthezied by Fusarium spp. (Nesic et al. 2014; Liuzzi et al. 2017). The metabolic burden is also higher when several toxins are found in the same feed (Milićević et al. 2010; Alshannaq and Yu 2017). With mass-based methods, the analysis of masked toxins (Berthiller et al. 2013; Gratz 2017) and metabolites (Warth et al. 2012; Streit et al. 2013; Abdallah et al. 2017) in the feed is a real possibility. Furthermore, mycotoxin secondary product analysis in other related matrices food matrices is promising (Escrivá et al. 2017).

\section{Mycotoxin seasonality}

With exception of levels for $\mathrm{AFB}_{2}\left(r^{2}=10.762 ; p=\right.$ $0.0212)$ and T-2 toxin $\left(r^{2}=31, p<<0.0001\right)$, no other toxin seem to associate with the sampling date. For this two toxins the latter result indicates that as the year progresses (in Costa Rica, dry season and rainy season are defined as per mean precipitation, the former demarcated by the months between December and April where $x<80 \mathrm{~mm}$ rain) $\mathrm{AFB}_{2}$ and $\mathrm{T}-2$ toxin increase. However, in general terms, toxin prevalence did increased during the month of September-November. Toxins 3-acetyldeoxynivalenol (Fig. 4a), T-2 toxin (Fig. 4b), enniatin B (Fig. 4c), both fumonisin fractions (Fig. $4 d$ ) aflatoxin fraction $B_{2}$ and $B_{1}$ (Fig. 4e) and zearalenone (Fig. 4f) showed this trend. In contrast, aflatoxin $G$ fractions showed a more scattered behavior (Fig. 4f). Ample scattering was also true for deoxynivalenol (Fig. 4a) and enniatin $B_{1}$ (Fig. 4b) and most metabolites such as 15-acetyldeoxynivalenol (Fig. 4a), HT-2 toxin (Fig. 4b), $\alpha$-zearalenol (Fig. 4f). An increase in toxin prevalence in September could correspond to the start of the rainiest part of the season in the country. This specific month exhibited, for 2018, a precipitation ranging from 93.4 to 
Table 4 Prevalence of mycotoxin contamination in agricultural commodities intended for animal consumption in Costa Rica

\begin{tabular}{|c|c|c|c|c|c|c|c|}
\hline \multicolumn{5}{|c|}{ Samples (n, counts) } & \multirow{3}{*}{$\begin{array}{l}\text { Prevalence, \%[Samples } \\
\text { over limit of detection, } \\
\text { (n)] }\end{array}$} & \multirow{3}{*}{$\begin{array}{l}\text { Minimum mycotoxin } \\
\text { concentration } \\
\pm U_{x} / x, \mu g \mathrm{~kg}^{-1}\end{array}$} & \multirow{2}{*}{$\begin{array}{l}\text { Maximum mycotoxin } \\
\text { concentration } \\
\pm U_{x} / x, \mu \mathrm{kg}^{-1}\end{array}$} \\
\hline \multicolumn{5}{|c|}{ Concentration range ${ }^{a}, \mu g \mathrm{~kg}^{-1}$} & & & \\
\hline$x<$ LoD & $x<5$ & $5 \leq x<10$ & $10 \leq x<20$ & $x \geq 20$ & & & \\
\hline \multicolumn{8}{|c|}{ Aflatoxin $B_{2}$} \\
\hline 196 & 6 & 0 & 2 & 1 & $4.39[9]$ & $0.46 \pm 0.06$ & $22.39 \pm 2.73$ \\
\hline \multicolumn{8}{|c|}{ Aflatoxin $G_{1}$} \\
\hline 195 & 9 & 0 & 0 & 1 & $4.88[10]$ & $0.13 \pm 0.01$ & $22.95 \pm 2.80$ \\
\hline \multicolumn{8}{|c|}{ Aflatoxin $B_{1}$} \\
\hline 193 & 11 & 0 & 1 & 0 & $5.85[12]$ & $0.016 \pm 0.002$ & $12.61 \pm 1.54$ \\
\hline \multicolumn{8}{|c|}{ Aflatoxin $G_{2}$} \\
\hline 179 & 24 & 1 & 1 & 0 & $12.68[26]$ & $0.054 \pm 0.007$ & $19.14 \pm 2.34$ \\
\hline$x<$ LoD & $x<250$ & $250 \leq x<500$ & $500 \leq x<1000$ & $x \geq 1000$ & & & \\
\hline \multicolumn{8}{|c|}{$\beta$-zearalenol } \\
\hline 202 & 1 & 0 & 1 & 1 & $1.46[3]$ & $228.03 \pm 27.86$ & $1900.62 \pm 232.24$ \\
\hline \multicolumn{8}{|c|}{ Nivalenol } \\
\hline 199 & 5 & 0 & 0 & 1 & $2.93[6]$ & $16.71 \pm 2.04$ & $1202.75 \pm 146.98$ \\
\hline \multicolumn{8}{|c|}{ 3-acetyldeoxynivalenol } \\
\hline 186 & 11 & 3 & 3 & 1 & 8.78 [18] & $1.88 \pm 0.23$ & $3236.56 \pm 395.51$ \\
\hline \multicolumn{8}{|c|}{ 15-acetyldeoxynivalenol } \\
\hline 186 & 16 & 3 & 0 & 0 & $9.27[19]$ & $1.74 \pm 0.21$ & $355.60 \pm 43.45$ \\
\hline \multicolumn{8}{|c|}{ a-zearalenol } \\
\hline 183 & 20 & 1 & 1 & 0 & $10.73[22]$ & $0.25 \pm 0.03$ & $920.65 \pm 112.50$ \\
\hline \multicolumn{8}{|c|}{ Deoxynivalenol } \\
\hline 180 & 24 & 1 & 0 & 0 & $12.20[25]$ & $0.20 \pm 0.02$ & $364.10 \pm 44.49$ \\
\hline \multicolumn{8}{|c|}{ Zearalenone } \\
\hline 170 & 18 & 8 & 4 & 5 & $24.75[35]$ & $70.37 \pm 80.60$ & $6518.28 \pm 796.54$ \\
\hline$x<$ LoD & $50<x$ & $125 \leq x<250$ & $250 \leq x<500$ & $x \geq 500$ & & & \\
\hline \multicolumn{8}{|c|}{ Fusarenone-X } \\
\hline 203 & 0 & 0 & 0 & 2 & $0.98[2]$ & $64.49 \pm 7.93$ & $470.52 \pm 57.99$ \\
\hline \multicolumn{8}{|c|}{ Diacetoxyscirpenol } \\
\hline 198 & 2 & 1 & 3 & 1 & $3.41[7]$ & $42.92 \pm 5.25$ & $1132.19 \pm 138.34$ \\
\hline \multicolumn{8}{|c|}{ Citrinin } \\
\hline 197 & 8 & 0 & 0 & 0 & $3.90[8]$ & $0.34 \pm 0.03$ & $52.48 \pm 6.41$ \\
\hline$x<$ LoD & $5<x$ & $10 \leq x<25$ & $25 \leq x<50$ & $x \geq 50$ & & & \\
\hline \multicolumn{8}{|c|}{ Patulin } \\
\hline 203 & 0 & 0 & 0 & 2 & $0.98[2]$ & $56.65 \pm 6.92$ & $88.56 \pm 10.82$ \\
\hline \multicolumn{8}{|c|}{ Neosolaniol } \\
\hline 201 & 0 & 0 & 1 & 3 & $1.95[4]$ & $49.52 \pm 6.05$ & $911.64 \pm 111.39$ \\
\hline \multicolumn{8}{|c|}{ Ochratoxin B } \\
\hline 199 & 2 & 2 & 1 & 1 & $2.93[6]$ & $6.28 \pm 0.77$ & $180.50 \pm 22.05$ \\
\hline \multicolumn{8}{|c|}{ Ochratoxin A } \\
\hline 184 & 3 & 3 & 4 & 11 & $10.24[21]$ & $3.64 \pm 0.44$ & $590.79 \pm 72.19$ \\
\hline
\end{tabular}


Table 4 Prevalence of mycotoxin contamination in agricultural commodities intended for animal consumption in Costa Rica (Continued)

\begin{tabular}{|c|c|c|c|c|c|c|c|}
\hline Samples & , counts) & & & & \multirow[t]{2}{*}{$\begin{array}{l}\text { Prevalence, \%[Samples } \\
\text { over limit of detection, } \\
\text { (n)] }\end{array}$} & \multirow[t]{2}{*}{$\begin{array}{l}\text { Minimum mycotoxin } \\
\text { concentration } \\
\pm U_{x} / x, \mu g k^{-1}\end{array}$} & \multirow[t]{2}{*}{$\begin{array}{l}\text { Maximum mycotoxin } \\
\text { concentration } \\
\pm U_{x} / x, \mu g \mathrm{~kg}^{-1}\end{array}$} \\
\hline$x<$ LoD & $x<250$ & $250 \leq x<500$ & $500 \leq x<1000$ & $x \geq 1000$ & & & \\
\hline \multicolumn{8}{|c|}{ Sterigmatocystin } \\
\hline 199 & 0 & 2 & 2 & 2 & $2.93[6]$ & $330.02 \pm 40.32$ & $1246.54 \pm 152.32$ \\
\hline \multicolumn{8}{|c|}{ Enniatin $B_{1}$} \\
\hline 190 & 15 & 0 & 0 & 0 & $7.32[15]$ & $0.16 \pm 0.02$ & $158.43 \pm 19.36$ \\
\hline \multicolumn{8}{|c|}{ T-2 toxin } \\
\hline 187 & 17 & 1 & 0 & 0 & $8.78[18]$ & $1.67 \pm 0.20$ & $254.17 \pm 31.06$ \\
\hline \multicolumn{8}{|c|}{ HT-2 toxin } \\
\hline 181 & 23 & 1 & 0 & 0 & $11.71[24]$ & $6.38 \pm 0.78$ & $303.22 \pm 37.05$ \\
\hline \multicolumn{8}{|c|}{ Enniatin B } \\
\hline 174 & 5 & 11 & 10 & 5 & $15.12[31]$ & $143.11 \pm 17.49$ & $3566.81 \pm 435.83$ \\
\hline$x<$ LoD & $x<1250$ & $1250 \leq x<2500$ & $2500 \leq x<5000$ & $x \geq 5000$ & & & \\
\hline \multicolumn{8}{|c|}{ Fumonisin $B_{1}$} \\
\hline 103 & 92 & 6 & 4 & 0 & $49.76[102]$ & $43.64 \pm 5.33$ & $4554.36 \pm 556.36$ \\
\hline \multicolumn{8}{|c|}{ Fumonisin $B_{2}$} \\
\hline 95 & 88 & 10 & 8 & 4 & $53.66[110]$ & $24.01 \pm 2.93$ & $8646.67 \pm 1056.64$ \\
\hline
\end{tabular}

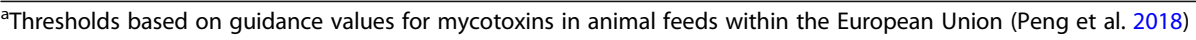

$667.8 \mathrm{~mm}$ and 11 to 29 rainy days. However, we already established for aflatoxins alone that no clear association was found between aflatoxin prevalence and season, in a tropical country such as Costa Rica (Granados-Chinchilla et al. 2017). Although this contrasts with findings in other countries with more defined seasons for feed and ingredients alike (Abdou et al. 2017; Blandino et al. 2017). Furthermore, prediction of toxin behavior and seasonal variations are more challenging due to climate change (van der Fels-Klerx et al. 2016a).

\section{Method application for antimicrobial residues in feed Residues found in feed routine samples}

Table 7 also shows the veterinary residues found in the feed samples, including some ionophores, tetracyclines, and florfenicol, among others. From the total of samples collected for veterinary residue assay, $7.9 \%(n=7 / 89)$ belong to feed samples declared as medicated for poultry and pigs, mainly for starting and finishing stages. Antibiotics used in animal early life stages are intended to improve health and performance and diminish morbidity and mortality in the individuals who are referred to the next production stage (Anadón et al. 2018; Mehdi et al. 2018). On another hand, the use of antimicrobials at the end of the production cycle is designed to improve animal weight gain and feed efficiency (Cancho Grande et al. 2000). Concentrations higher than those guaranteed or failure to report the antibiotic as a feed ingredient may render withdrawal periods useless. Furthermore, evidence suggests that antibiotic performance enhancing capabilities is lost during the later stages of growth and at the time of commercial processing (Kumar et al. 2018). $57.14 \%$ of the medicated samples contained no detectable antibiotics $(n=4 / 7)$, though the label stated otherwise. The remaining $42.86 \%$ of the samples $(n=3$ / 7) presented qualitative or quantitative incongruences regarding the concentration of analytes declared on the labels or the antibiotics found. On another hand, 74.6\% $(n=50 / 67)$ of the non-medicated feed samples analyzed, exhibit veterinary residues (Table 7 ).

\section{Permitted legal usage}

Current European Union (Anadón et al. 2018) and US FDA (FAO 2002; FDA 2013; FDA 2018) regulations dictate antibiotic usage in the feed. In-feed therapeutic applications are allowed under some restrictions (European Comission 2001; European Comission 2004; FDA 2013; Anadón et al. 2018). Growth promotion under these circumstances is limited by withdrawal which ensures the reduction of drug persistence on food products for human consumption (Cancho Grande et al. 2000; Anadón et al. 2018; Tang et al. 2017) and resistant isolates in the animal (Beukers et al. 2015; Tang et al. 2017). We found antibiotic residues in medicated and non-medicated feed samples that conflict with said guidance. In medicated animal feeds, it is observed that narasin has concentrations of 44.03 and $227.68 \mathrm{mg} \mathrm{kg}^{-1}$, in poultry feeds, the last value exceeds that allowed by the FDA (Table 7). In 
Table 5 Prevalence of mycotoxin contamination presented by feed matrix ${ }^{a}$

\begin{tabular}{|c|c|c|c|c|}
\hline Average \pm standard deviation & $\begin{array}{l}\text { Maximum mycotoxin } \\
\text { concentration } \\
\pm U_{x} / x, \mu \mathrm{kg}^{-1}\end{array}$ & $\begin{array}{l}\text { Minimum mycotoxin } \\
\text { concentration } \\
\pm U_{x} / x, \mu g \mathrm{~kg}^{-1}\end{array}$ & $\begin{array}{l}\text { Number of samples } \\
\text { above recommended } \\
\text { guideline/legislative } \\
\text { threshold }\end{array}$ & $\begin{array}{l}\text { Prevalence, \%[Samples } \\
\text { over limit of detection, } \\
\text { (n)] }\end{array}$ \\
\hline
\end{tabular}

Feed ingredients ( $n=$ number of events over limit of detection)

Rice meal $(n=2)$

Zearalenone $\left(2000 \mathrm{\mu g} \mathrm{kg}^{-1}\right)$

$212.64 \pm 25.98$

$6.38 \pm 0.78$

0

100.00 [2]

Forage $(n=9)$

Aflatoxin $\mathrm{G}_{2}\left(50 \mathrm{\mu g} \mathrm{kg}^{-1} \text { total aflatoxins }\right)^{c}$

$1.54 \pm 0.24$

$1.78 \pm 0.22$

$1.30 \pm 0.16$

0

$22.22[2]$

Citrinin

$18.28 \pm 11.58$

$29.86 \pm 3.65$

$6.71 \pm 0.82$

0

22.22 [2]

a-zearalenone

$13.76 \pm 1.17$

$14.93 \pm 1.82$

$12.60 \pm 1.54$

$22.22[2]$

Aflatoxin $B_{2}\left(50 \mu \mathrm{g} \mathrm{kg}^{-1}\right.$ total aflatoxins) ${ }^{\mathrm{c}}$

$3.01 \pm 1.57$

$4.58 \pm 0.56$

$0.87 \pm 0.11$

33.33 [3]

Wheat Middlings $(n=11)$

3-acetyldeoxynivalenol

$1630.85 \pm 1605.71$

$3566.81 \pm 435.83$

$2465.29 \pm 301.24$

18.18 [2]

Aflatoxin $B_{1}\left(50 \mathrm{\mu g} \mathrm{kg}^{-1}\right.$ total aflatoxins) ${ }^{c}$

$0.055 \pm 0.038$

$0.093 \pm 0.011$

$0.016 \pm 0.002$

0

$18.18[2]$

Enniatin B

$3016.05 \pm 550.76$

$3566.81 \pm 435.83$

$2465.29 \pm 301.24$

18.18 [2]

Enniatin $B_{1}$

$23.91 \pm 19.48$

$43.39 \pm 5.30$

$4.43 \pm 0.54$

$18.18[2]$

Fumonisin $\mathrm{B}_{1}\left(60,000 \mu \mathrm{g} \mathrm{kg}^{-1} \mathrm{FB}_{1}+\mathrm{FB}_{2}\right)^{\mathrm{C}}$

$707.74 \pm 282.62$

$1043.86 \pm 127.55$

$352.39 \pm 43.06$

$27.27[3]$

Soybean meal $(n=14)$

Diacetoxyscirpenol

$324.61 \pm 22.83$

$347.43 \pm 42.45$

$301.78 \pm 36.88$

14.29 [2]

HT-2 toxin $\left(500 \mu^{-k g ~ k g^{-1}}\right.$ sum T-2/HT-2) ${ }^{\mathrm{c}}$

$97.03 \pm 76.52$

$173.55 \pm 21.21$

$20.50 \pm 2.51$

0

14.29 [2]

Ochratoxin B

$108.60 \pm 71.90$

$180.50 \pm 22.06$

$36.69 \pm 4.48$

14.29 [2]

T-2 toxin

$24.37 \pm 19.75$

$44.12 \pm 5.39$

$4.61 \pm 0.56$

0

14.29 [2]

Deoxynivalenol $\left(8000 \mathrm{\mu g} \mathrm{kg}^{-1}\right)^{\mathrm{c}}$

$88.49 \pm 127.88$

$364.11 \pm 44.49$

$1.56 \pm 0.19$

0

42.86 [6]

Corn meal $(n=40)$

Aflatoxin $\mathrm{G}_{1}\left(50 \mathrm{\mu g} \mathrm{kg}^{-1} \text { total aflatoxins }\right)^{c}$

$0.40 \pm 0.13$

$0.53 \pm 0.07$

$0.27 \pm 0.03$

0

$5.00[2]$

Deoxynivalenol $\left(8000 \mathrm{\mu g} \mathrm{kg}^{-1}\right)^{\mathrm{c}}$

$18.51 \pm 2.84$

$21.35 \pm 2.61$

$15.67 \pm 1.91$

0

5.00 [2]

Nivalenol

$95.23 \pm 70.59$ 
Table 5 Prevalence of mycotoxin contamination presented by feed matrix ${ }^{a}$ (Continued)

\begin{tabular}{|c|c|c|c|c|}
\hline Average \pm standard deviation & $\begin{array}{l}\text { Maximum mycotoxin } \\
\text { concentration } \\
\pm U_{x} / x, \mu g \mathrm{~kg}^{-1}\end{array}$ & $\begin{array}{l}\text { Minimum mycotoxin } \\
\text { concentration } \\
\pm U_{x} / x_{1} \mu \mathrm{kg}^{-1}\end{array}$ & $\begin{array}{l}\text { Number of samples } \\
\text { above recommended } \\
\text { guideline/legislative } \\
\text { threshold }\end{array}$ & $\begin{array}{l}\text { Prevalence, \%[Sam } \\
\text { over limit of detec } \\
\text { (n)] }\end{array}$ \\
\hline \multicolumn{5}{|l|}{ Ochratoxin B } \\
\hline $6.43 \pm 0.15$ & $6.57 \pm 0.80$ & $6.28 \pm 0.77$ & 0 & $5.00[2]$ \\
\hline \multicolumn{5}{|l|}{ a-zearalenone } \\
\hline $38.43 \pm 0.15$ & $76.61 \pm 9.36$ & $0.26 \pm 0.03$ & 0 & $5.00[2]$ \\
\hline \multicolumn{5}{|l|}{ 15-acetyldeoxynivalenol } \\
\hline $103.53 \pm 129.77$ & $286.92 \pm 35.06$ & $6.10 \pm 0.74$ & 0 & $7.50[3]$ \\
\hline \multicolumn{5}{|c|}{ Aflatoxin $B_{1}\left(50 \mu \mathrm{g} \mathrm{kg}^{-1} \text { total aflatoxins }\right)^{c}$} \\
\hline $0.93 \pm 0.14$ & $1.13 \pm 0.14$ & $0.82 \pm 0.10$ & 0 & $7.50[3]$ \\
\hline \multicolumn{5}{|l|}{ Zearalenone $\left(2000 \mathrm{\mu g} \mathrm{kg}^{-1}\right)$} \\
\hline $917.53 \pm 969.07$ & $2287.31 \pm 279.49$ & $194.79 \pm 23.80$ & & $7.50[3]$ \\
\hline \multicolumn{5}{|l|}{ 3-acetyldeoxynivalenol } \\
\hline $685.86 \pm 388.15$ & $965.07 \pm 117.92$ & $16.20 \pm 1.98$ & 0 & $10.00[4]$ \\
\hline \multicolumn{5}{|c|}{ Fumonisin $B_{1}\left(60,000 \mu \mathrm{g} \mathrm{kg}^{-1} \mathrm{FB}_{1}+\mathrm{FB}_{2}\right)^{\mathrm{c}}$} \\
\hline $1050.06 \pm 906.51$ & $2926.98 \pm 357.65$ & $226.56 \pm 27.68$ & 0 & $20.00[8]$ \\
\hline \multicolumn{5}{|l|}{ Fumonisin $B_{2}$} \\
\hline $578.55 \pm 669.59$ & $2308.56 \pm 282.56$ & $106.59 \pm 13.02$ & 0 & $25.00[10$ \\
\hline
\end{tabular}

Compound feed

Shrimp feed $(n=2)$

Sterigmatocystin

$908.81+337.73$

$1246.54 \pm 152.32$

$571.09 \pm 69.78$

0

$100.00[2]$

Ingredients ${ }^{\text {bt. }}$ corn meal (max 15\%), soybean meal (max 75\%), DDGS, palm kernel meal (max 30\%), wheat middlings (max 20\%), rice meal and bran (max 15\%), soybean hulls.

Sheep feed $(n=6)$

Fumonisin $B_{1}\left(5000 \mu \mathrm{g} \mathrm{kg}^{-1} \mathrm{FB}_{1}+\mathrm{FB}_{2}\right)^{\mathrm{c}}$

$282.62 \pm 118.66$

$347.28 \pm 42.44$

$109.95 \pm 13.44$

0

$33.33[2]$

Fumonisin $B_{2}\left(5000 \mu \mathrm{g} \mathrm{kg}^{-1} \mathrm{FB}_{1}+\mathrm{FB}_{2}\right)^{\mathrm{c}}$
$120.72 \pm 40.23$
$160.95 \pm 19.67$
$80.49 \pm 9.84$
0
33.33 [2]

Zearalenone $\left(500 \mathrm{\mu g} \mathrm{kg}^{-1}\right)^{\mathrm{c}}$

$299.24 \pm 50.63$

$349.87 \pm 42.75$

$248.61 \pm 30.38$

0

33.33 [2]

Ingredients ${ }^{\text {bt }}$ : corn meal (max 45\%), Soybean meal (max 13\%), DDGS (max 20\%), palm kernel meal, wheat middlings (max 25\%), rice bran, soybean hulls (max 20\%).

Pet food (dog dry food, $n=8$ )

Aflatoxin $\mathrm{G}_{1}$

$3.10 \pm 0.77$

$3.86 \pm 0.47$

$2.33 \pm 0.28$

0

$25.00[2]$

Fumonisin $B_{1}\left(5000 \mu \mathrm{g} \mathrm{kg}^{-1} \mathrm{FB}_{1}+\mathrm{FB}_{2}\right)^{\mathrm{c}}$

$2007.52 \pm 1808.45$

$4554.36 \pm 556.51$

$531.75 \pm 64.98$

0

37.50 [3]

Fumonisin $B_{2}\left(5000 \mu \mathrm{gg}^{-1} \mathrm{FB}_{1}+\mathrm{FB}_{2}\right)^{\mathrm{c}}$

$2163.60 \pm 1106.76$

$1056.84 \pm 137.85$

$3270.36 \pm 426.57$

0

37.50 [3]

Ingredients $^{\mathrm{b}+}$ : corn meal (max 50\%), DDGS (max 25\%), palm kernel meal, wheat middlings (max 20\%), rice meal and bran (max 20\%).

Poultry feed $(n=16)$

Aflatoxin $\mathrm{G}_{1}\left(20 \mu \mathrm{g} \mathrm{kg}^{-1}\right.$ total aflatoxins) ${ }^{c}$

$0.78 \pm 0.85$

$1.97 \pm 0.24$

$0.05 \pm 0.01$

0

$18.75[3]$ 
Table 5 Prevalence of mycotoxin contamination presented by feed matrix ${ }^{a}$ (Continued)

\begin{tabular}{lllll}
\hline Average \pm standard deviation & Maximum mycotoxin & Minimum mycotoxin & Number of samples & Prevalence, \%[Samples \\
& concentration & concentration & above recommended & over limit of detection, \\
$\pm U_{x} / x, \mu g \mathrm{~kg}^{-1}$ & $\pm U_{x} / x, \mu \mathrm{g} \mathrm{kg}$ & guideline/legislative & (n)] \\
& & threshold &
\end{tabular}

\begin{tabular}{|c|c|c|c|c|}
\hline \multicolumn{5}{|c|}{ Deoxynivalenol $\left(5000 \mu \mathrm{g} \mathrm{kg}^{-1}\right)^{\mathrm{c}}$} \\
\hline $28.34 \pm 13.90$ & $42.24 \pm 5.16$ & $14.44 \pm 1.76$ & 0 & $12.50[3]$ \\
\hline \multicolumn{5}{|c|}{ Fumonisin $B_{2}\left(20,000 \mu \mathrm{gg}^{-1} \mathrm{FB}_{1}+\mathrm{FB}_{2}\right)^{c}$} \\
\hline $1897.00 \pm 2898.09$ & $6911.99 \pm 844.59$ & $72.19 \pm 8.82$ & 0 & $25.00[4]$ \\
\hline \multicolumn{5}{|c|}{ Fumonisin $B_{1}\left(20,000 \mu \mathrm{g} \mathrm{kg}^{-1} \mathrm{FB}_{1}+\mathrm{FB}_{2}\right)^{\mathrm{c}}$} \\
\hline $471.74 \pm 277.98$ & $953.09 \pm 116.46$ & $88.97 \pm 10.87$ & 0 & $37.50[6]$ \\
\hline \multicolumn{5}{|c|}{ 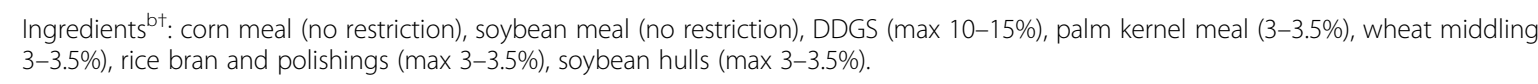 } \\
\hline \multicolumn{5}{|l|}{ Calf feed $(n=24)$} \\
\hline \multicolumn{5}{|c|}{ Deoxynivalenol $\left(2000 \mu \mathrm{g} \mathrm{kg}^{-1}\right)^{\mathrm{c}}$} \\
\hline $31.48 \pm 31.30$ & $62.79 \pm 7.67$ & $0.20 \pm 0.02$ & 0 & $8.33[2]$ \\
\hline \multicolumn{5}{|l|}{ Enniatin $B_{1}$} \\
\hline $36.28 \pm 36.13$ & $72.41 \pm 8.85$ & $0.15 \pm 0.02$ & 0 & $8.33[2]$ \\
\hline \multicolumn{5}{|l|}{ Enniatin B } \\
\hline $586.63 \pm 154.23$ & $711.74 \pm 86.97$ & $369.35 \pm 45.13$ & 0 & $12.50[3]$ \\
\hline \multicolumn{5}{|c|}{ HT-2 toxin $\left(500 \mu \mathrm{g} \mathrm{kg}^{-1}\right.$ sum T-2/HT-2) ${ }^{c}$} \\
\hline $88.15 \pm 69.86$ & $182.35 \pm 22.28$ & $15.28 \pm 1.87$ & 0 & $12.50[3]$ \\
\hline \multicolumn{5}{|c|}{ Fumonisin $B_{1}\left(20,000 \mu \mathrm{g} \mathrm{kg}^{-1} \mathrm{FB}_{1}+\mathrm{FB}_{2}\right)^{c}$} \\
\hline $446.45 \pm 117.84$ & $676.88 \pm 82.71$ & $293.22 \pm 35.83$ & 0 & $29.17[7]$ \\
\hline \multicolumn{5}{|c|}{ Fumonisin $B_{2}\left(20,000 \mu \mathrm{g} \mathrm{kg}^{-1} \mathrm{FB}_{1}+\mathrm{FB}_{2}\right)^{\mathrm{c}}$} \\
\hline $615.73 \pm 886.97$ & $2773.27 \pm 338.87$ & $102.46 \pm 12.52$ & 0 & $29.17[7]$ \\
\hline
\end{tabular}

Ingredients ${ }^{\text {bt }}$ : corn meal (no restriction), soybean meal (no restriction), DDGS (12-15\%), palm kernel meal (max 10-15\%), wheat middlings (max 10-20\%), rice bran and polishings (max 10-20\%), soybean hulls (max 10\%), citrus pulp (10\%).

Poultry layer feed $(n=28)$

3-acetyldeoxynivalenol

$166.14+33.98$

$200.13+24.45$

$132.16 \pm 16.15$

0

$7.14[2]$

Aflatoxin $\mathrm{G}_{1}\left(20 \mathrm{\mu g} \mathrm{kg}^{-1} \text { total aflatoxins }\right)^{c}$

$0.47 \pm 0.35$

$0.82 \pm 0.10$

$0.12 \pm 0.01$

0

$7.14[2]$

Zearalenone $\left(250 \mathrm{\mu g} \mathrm{kg}^{-1}\right)^{\mathrm{c}}$

$415.74 \pm 140.17$

$555.91 \pm 67.93$

$275.57 \pm 33.67$

2

$7.14[2]$

Deoxynivalenol $\left(5000 \mathrm{\mu g} \mathrm{kg}^{-1}\right)$

$42.98 \pm 7.38$

$50.36 \pm 6.15$

$35.60 \pm 4.35$

0

$7.14[2]$

HT-2 toxin (500 $\mathrm{\mu g} \mathrm{kg}^{-1}$ sum T-2/HT-2) ${ }^{\mathrm{c}}$

$8.45 \pm 6.11 \quad 16.81 \pm 2.05$

$0.0017 \pm 0.002$

0

$17.86[5]$

Fumonisin $B_{1}\left(20,000 \mu \mathrm{g} \mathrm{kg}^{-1} \mathrm{FB}_{1}+\mathrm{FB}_{2}\right)^{\mathrm{c}}$

$446.65 \pm 244.52$

$956.92 \pm 116.93$

$173.01 \pm 21.14$

0

$25.00[7]$

Fumonisin $B_{2}\left(20,000 \mu \mathrm{kg}^{-1} \mathrm{FB}_{1}+\mathrm{FB}_{2}\right)^{\mathrm{c}}$

$657.81 \pm 1079.21 \quad 3507.81 \pm 428.62$

$124.39 \pm 15.20$

0

$28.57[8]$

Ingredients ${ }^{\text {bt }}$ : corn meal (no restriction), soybean meal (no restriction), DDGS (max 10-15\%), palm kernel meal (3-3.5\%), wheat middlings (max $3-3.5 \%$ ), rice bran and polishings ( $\max 3-3.5 \%$ ), soybean hulls (max 3-3.5\%).

Beef cattle feed $(n=51)$

Aflatoxin $B_{2}\left(50 \mathrm{\mu g} \mathrm{kg}^{-1} \text { total aflatoxins }\right)^{c}$

$11.43 \pm 10.96$

$22.39 \pm 2.74$

$0.46 \pm 0.06$

1

3.92 [2] 
Table 5 Prevalence of mycotoxin contamination presented by feed matrix ${ }^{a}$ (Continued)

\begin{tabular}{|c|c|c|c|c|}
\hline Average \pm standard deviation & $\begin{array}{l}\text { Maximum mycotoxin } \\
\text { concentration } \\
\pm U_{x} / x, \mu g \mathrm{~kg}^{-1}\end{array}$ & $\begin{array}{l}\text { Minimum mycotoxin } \\
\text { concentration } \\
\pm U_{x} / x, \mu g \mathrm{~kg}^{-1}\end{array}$ & $\begin{array}{l}\text { Number of samples } \\
\text { above recommended } \\
\text { guideline/legislative } \\
\text { threshold }\end{array}$ & $\begin{array}{l}\text { Prevalence, \%[Samples } \\
\text { over limit of detection, } \\
\text { (n)] }\end{array}$ \\
\hline \multicolumn{5}{|l|}{ Aflatoxin $G_{1}$} \\
\hline $2.08 \pm 1.79$ & $1.94 \pm 1.86$ & $3.79 \pm 0.46$ & 0 & $3.92[2]$ \\
\hline \multicolumn{5}{|c|}{ Zearalenone $\left(500 \mathrm{\mu g} \mathrm{kg}^{-1}\right)^{\mathrm{c}}$} \\
\hline $281.79 \pm 134.83$ & $416.62 \pm 50.91$ & $146.95 \pm 17.96$ & 0 & $3.92[2]$ \\
\hline \multicolumn{5}{|l|}{ 15-acetyldeoxynivalenol } \\
\hline $23.40 \pm 17.96$ & $41.36 \pm 5.05$ & $5.44 \pm 0.66$ & 0 & $3.92[2]$ \\
\hline \multicolumn{5}{|c|}{ Deoxynivalenol $\left(5000 \mathrm{\mu g} \mathrm{kg}^{-1}\right)^{c}$} \\
\hline $26.21 \pm 6.69$ & $32.90 \pm 4.02$ & $19.52 \pm 2.39$ & 0 & $3.92[2]$ \\
\hline \multicolumn{5}{|l|}{ Enniatin B } \\
\hline $638.80 \pm 279.21$ & $1115.50 \pm 136.30$ & $239.59 \pm 29.28$ & 0 & $9.80[5]$ \\
\hline \multicolumn{5}{|l|}{ Enniatin $B_{1}$} \\
\hline $25.09 \pm 6.86$ & $34.56 \pm 4.22$ & $18.50 \pm 2.26$ & 0 & $5.88[3]$ \\
\hline \multicolumn{5}{|l|}{ a-zearalenone } \\
\hline $20.37 \pm 8.41$ & $32.24 \pm 3.94$ & $13.83 \pm 1.69$ & 0 & $5.88[3]$ \\
\hline \multicolumn{5}{|c|}{ Ochratoxin A $\left(250 \mathrm{\mu g} \mathrm{kg}^{-1}\right)^{\mathrm{c}}$} \\
\hline $176.26 \pm 171.92$ & $525.17 \pm 64.17$ & $12.38 \pm 1.51$ & 2 & $15.69[8]$ \\
\hline \multicolumn{5}{|c|}{ Fumonisin $B_{1}\left(50,000 \mu \mathrm{gg}^{-1} \mathrm{FB}_{1}+\mathrm{FB}_{2}\right)^{\mathrm{c}}$} \\
\hline $554.52 \pm 374.96$ & $1635.38 \pm 199.83$ & $227.42 \pm 27.79$ & 0 & $21.57[11]$ \\
\hline \multicolumn{5}{|c|}{ Fumonisin $B_{2}\left(50,000 \mu \mathrm{g} \mathrm{kg}^{-1} \mathrm{FB}_{1}+\mathrm{FB}_{2}\right)^{\mathrm{c}}$} \\
\hline $570.07 \pm 816.10$ & $3013.12 \pm 368.18$ & $38.27 \pm 4.68$ & 0 & 21.57 [11] \\
\hline
\end{tabular}

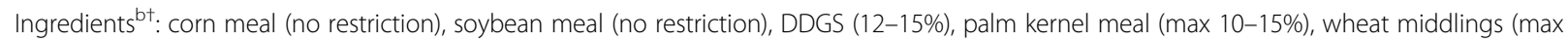
$10-20 \%$ ), rice bran and polishings (max 10-20\%), soybean hulls (max 10\%), citrus pulp (10\%).

Swine feed (lactating and gestating sows and pig grower, $n=54$ )

Aflatoxin $\mathrm{G}_{1}\left(20 \mathrm{\mu g} \mathrm{kg}^{-1}\right.$ total aflatoxins) ${ }^{c}$

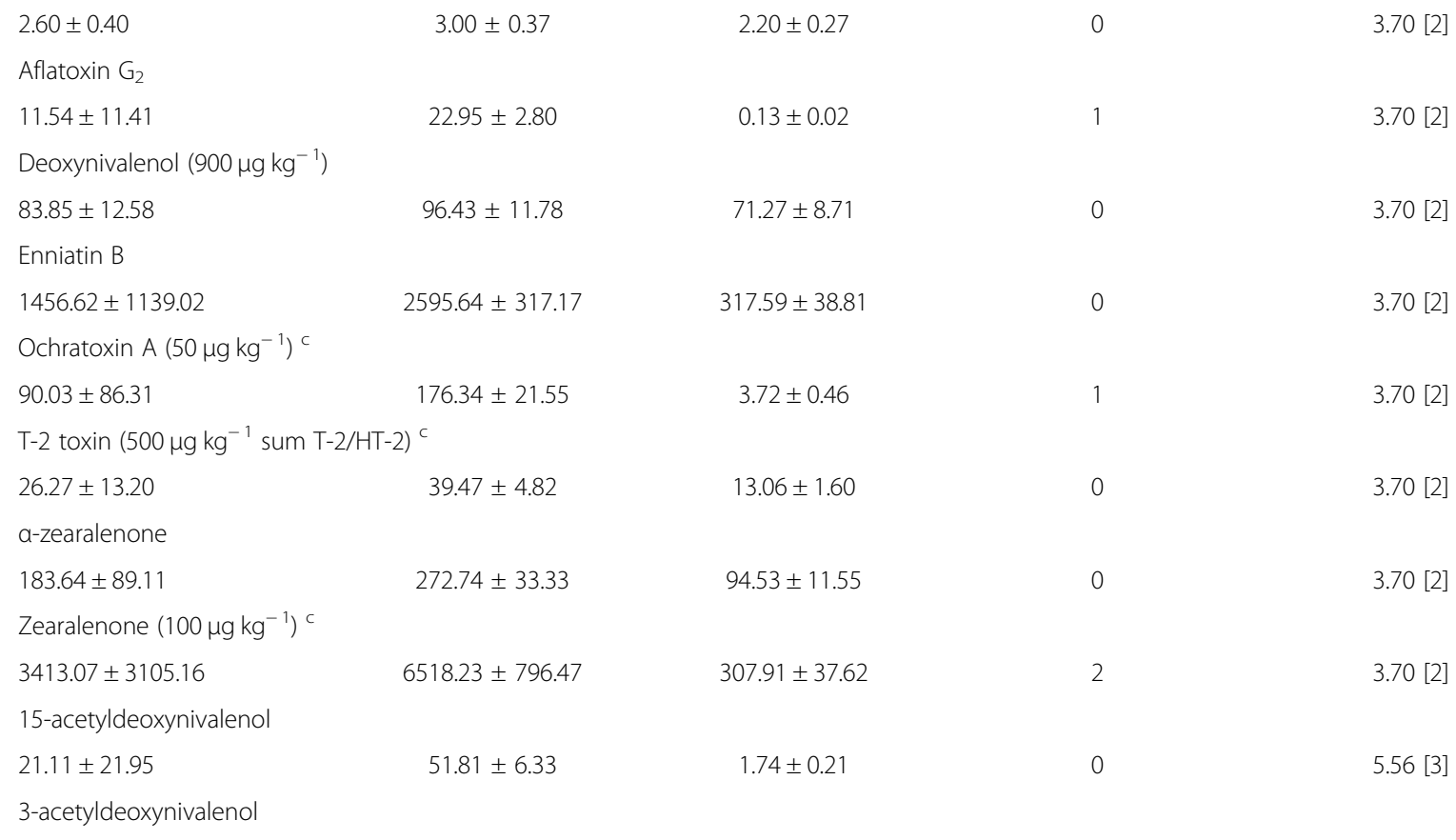


Table 5 Prevalence of mycotoxin contamination presented by feed matrix ${ }^{a}$ (Continued)

\begin{tabular}{|c|c|c|c|c|}
\hline Average \pm standard deviation & $\begin{array}{l}\text { Maximum mycotoxin } \\
\text { concentration } \\
\pm U_{x} / x, \mu g \mathrm{~kg}^{-1}\end{array}$ & $\begin{array}{l}\text { Minimum mycotoxin } \\
\text { concentration } \\
\pm U_{x} / x, \mu g \mathrm{~kg}^{-1}\end{array}$ & $\begin{array}{l}\text { Number of samples } \\
\text { above recommended } \\
\text { guideline/legislative } \\
\text { threshold }\end{array}$ & $\begin{array}{l}\text { Prevalence, \%[Samples } \\
\text { over limit of detection, } \\
\text { (n)] }\end{array}$ \\
\hline $97.43 \pm 108.61$ & $279.19 \pm 34.11$ & $6.84 \pm 0.84$ & 0 & $5.56[3]$ \\
\hline \multicolumn{5}{|c|}{ HT-2 toxin $\left(500 \mu \mathrm{g} \mathrm{kg}^{-1}\right.$ sum T-2/HT-2) ${ }^{c}$} \\
\hline $24.02 \pm 9.15$ & $36.28 \pm 4.43$ & $14.31 \pm 1.75$ & 0 & $5.56[3]$ \\
\hline \multicolumn{5}{|c|}{ Fumonisin $B_{1}\left(5000 \mu \mathrm{g} \mathrm{kg}^{-1} \mathrm{FB}_{1}+\mathrm{FB}_{2}\right)^{\mathrm{c}}$} \\
\hline $701.61 \pm 718.91$ & $2715.10 \pm 331.76$ & $233.69 \pm 28.55$ & 0 & $25.93[14]$ \\
\hline \multicolumn{5}{|c|}{ Fumonisin $B_{2}\left(5000 \mu \mathrm{g} \mathrm{kg}^{-1} \mathrm{FB}_{1}+\mathrm{FB}_{2}\right)^{\mathrm{c}}$} \\
\hline $1395.61 \pm 2149.99$ & $8019.99 \pm 979.98$ & $103.26 \pm 12.62$ & 1 & $25.93[14]$ \\
\hline \multicolumn{5}{|c|}{$\begin{array}{l}\text { Ingredients }{ }^{\text {bt. }} \text { corn meal (no restriction), soybean meal (no restriction), DDGS (max 10\%), palm kernel meal (max 10\%), wheat middlings (max } \\
20-25 \%) \text {, rice bran and polishing (max 20-25\%), soybean hulls (no restriction). }\end{array}$} \\
\hline \multicolumn{5}{|l|}{ Dairy cattle feed $(n=186)$} \\
\hline \multicolumn{5}{|c|}{ Aflatoxin $B_{1}\left(50 \mu \mathrm{g} \mathrm{kg}^{-1} \text { total aflatoxins }\right)^{c}$} \\
\hline $0.15 \pm 0.04$ & $0.19 \pm 0.02$ & $0.11 \pm 0.01$ & 0 & $1.07[2]$ \\
\hline \multicolumn{5}{|l|}{ Neosolaniol } \\
\hline $57.14 \pm 7.61$ & $64.75 \pm 7.91$ & $49.53 \pm 6.05$ & 0 & $1.07[2]$ \\
\hline \multicolumn{5}{|l|}{ Ochratoxin B } \\
\hline $16.41 \pm 4.04$ & $20.45 \pm 2.50$ & $12.37 \pm 1.51$ & 0 & $1.07[2]$ \\
\hline \multicolumn{5}{|l|}{ Sterigmatocystin } \\
\hline $387.83 \pm 57.81$ & $445.63 \pm 54.45$ & $330.02 \pm 40.33$ & 0 & $1.07[2]$ \\
\hline \multicolumn{5}{|l|}{$\beta$-zearalenone } \\
\hline $499.65 \pm 271.62$ & $771.27 \pm 94.24$ & $228.03 \pm 27.86$ & 0 & $1.07[2]$ \\
\hline \multicolumn{5}{|l|}{ 15-acetyldeoxynivalenol } \\
\hline $29.94 \pm 8.99$ & $38.38 \pm 4.69$ & $17.49 \pm 2.14$ & 0 & $1.62[3]$ \\
\hline \multicolumn{5}{|l|}{ 3-acetyldeoxynivalenol } \\
\hline $159.61 \pm 145.15$ & $352.24 \pm 43.04$ & $1.88 \pm 0.23$ & 0 & $1.62[3]$ \\
\hline \multicolumn{5}{|l|}{ Aflatoxin $G_{2}$} \\
\hline $1.43 \pm 1.32$ & $3.49 \pm 0.43$ & $0.24 \pm 0.03$ & 0 & $2.15[4]$ \\
\hline \multicolumn{5}{|l|}{ Citrinin } \\
\hline $21.86 \pm 19.03$ & $52.48 \pm 6.41$ & $3.51 \pm 0.43$ & 0 & $2.15[4]$ \\
\hline \multicolumn{5}{|l|}{ Enniatin $B_{1}$} \\
\hline $58.67 \pm 29.56$ & $104.91 \pm 12.82$ & $27.14 \pm 3.32$ & 0 & $2.69[5]$ \\
\hline \multicolumn{5}{|c|}{ Ochratoxin A $\left(250 \mu \mathrm{gg}^{-1}\right)^{c}$} \\
\hline $50.99 \pm 56.73$ & $158.70 \pm 19.39$ & $3.67 \pm 0.45$ & 0 & $2.69[5]$ \\
\hline \multicolumn{5}{|l|}{ Deoxynivalenol } \\
\hline $25.87 \pm 26.44$ & $82.60 \pm 10.09$ & $0.75 \pm 0.09$ & 0 & $3.22[6]$ \\
\hline \multicolumn{5}{|l|}{ Aflatoxin $\mathrm{G}_{1}$} \\
\hline $2.95 \pm 1.31$ & $5.75 \pm 0.70$ & $1.60 \pm 0.19$ & 0 & $3.76[7]$ \\
\hline \multicolumn{5}{|c|}{ T-2 toxin $\left(500 \mu \mathrm{g} \mathrm{kg}^{-1}\right.$ sum T-2/HT-2) ${ }^{c}$} \\
\hline $47.19 \pm 44.97$ & $137.81 \pm 16.84$ & $1.67 \pm 0.20$ & 0 & $4.30[8]$ \\
\hline \multicolumn{5}{|l|}{$\mathrm{HT}-2$ toxin } \\
\hline $60.14 \pm 88.86$ & $303.22 \pm 37.05$ & $5.02 \pm 0.61$ & 0 & $5.38[10]$ \\
\hline \multicolumn{5}{|l|}{ a-zearalenone } \\
\hline $38.05 \pm 24.95$ & $96.21 \pm 11.76$ & $8.40 \pm 1.03$ & 0 & 5.38 [10] \\
\hline
\end{tabular}


Table 5 Prevalence of mycotoxin contamination presented by feed matrix ${ }^{a}$ (Continued)

\begin{tabular}{|c|c|c|c|c|}
\hline Average \pm standard deviation & $\begin{array}{l}\text { Maximum mycotoxin } \\
\text { concentration } \\
\pm U_{x} / x, \mu g \mathrm{~kg}^{-1}\end{array}$ & $\begin{array}{l}\text { Minimum mycotoxin } \\
\text { concentration } \\
\pm U_{x} / x, \mu g \mathrm{~kg}^{-1}\end{array}$ & $\begin{array}{l}\text { Number of samples } \\
\text { above recommended } \\
\text { guideline/legislative } \\
\text { threshold }\end{array}$ & $\begin{array}{l}\text { Prevalence, \%[Samp } \\
\text { over limit of detect } \\
\text { (n)] }\end{array}$ \\
\hline \multicolumn{5}{|l|}{ Enniatin B } \\
\hline $477.01 \pm 259.96$ & $914.05 \pm 111.69$ & $147.78 \pm 18.06$ & 0 & $6.99[13]$ \\
\hline \multicolumn{5}{|l|}{ Zearalenone $\left(250 \mathrm{\mu g} \mathrm{kg}^{-1}\right)^{\mathrm{c}}$} \\
\hline $294.51 \pm 286.20$ & $1107.81 \pm 135.37$ & $54.54 \pm 6.66$ & 3 & $8.06[15]$ \\
\hline \multicolumn{5}{|c|}{ Fumonisin $\mathrm{B}_{1}\left(50,000 \mu \mathrm{g} \mathrm{kg}^{-1} \mathrm{FB}_{1}+\mathrm{FB}_{2}\right)^{\mathrm{c}}$} \\
\hline $460.62 \pm 508.11$ & $3133.88 \pm 382.93$ & $124.77 \pm 15.25$ & 0 & $19.89[37]$ \\
\hline \multicolumn{5}{|c|}{ Fumonisin $B_{2}\left(50,000 \mu \mathrm{g} \mathrm{kg}^{-1} \mathrm{FB}_{1}+\mathrm{FB}_{2}\right)^{\mathrm{c}}$} \\
\hline $685.45 \pm 1321.61$ & $8088.95 \pm 988.40$ & $52.76 \pm 6.45$ & 0 & $24.73[46]$ \\
\hline
\end{tabular}

Ingredients $^{\mathrm{bt}}$ : corn meal (no restriction), soybean meal (no restriction), DDGS (12-15\%), palm kernel meal (max 10-15\%), wheat middlings (max $10-20 \%$ ), rice bran and polishings (max 10-20\%), soybean hulls (max 10\%), citrus pulp (10\%).

${ }^{a}$ Only samples with $n>1$ and toxins with more than one incident were included

bPlant-derived constituents according to guaranteed labels, data in parenthesis indicates maximum inclusion recommended for each ingredient during feed formulation. ${ }^{\dagger}$ FAO (2018), INRA (2012), FEDIAF (2016), Martínez Marín (2008), NRC (2001), Rostagno et al. (2017)

'Data in parenthesis indicates maximum permitted or recommended toxin concentrations (Pettersson 2012)

non-medicated feeds, the situation is more worrisome, since concentrations have been found that exceed the recommended values, including phases of production in which its use is prohibited, as in the case of feed for laying hens with $191.69 \mathrm{mg} \mathrm{kg}^{-1}$ of monensin or dairy cattle with $3258.86 \mathrm{mg} \mathrm{kg}^{-1}$ (Table 7, FDA, 2011). Monensin and narasin presence can be explained as, widespread since ionophore-based growth promotion is still allowed (Granados-Chinchilla and Rodríguez 2017) and they are commonly used to fight causative agents of coccidiosis in aviculture (specifically for broilers, and laying hens before starting the production period) in concentrations of $90-110$ and $54-72 \mathrm{mg} \mathrm{kg}^{-1}$ respectively (Table 7, FDA 2011; Kant et al. 2013). We also found tetracyclines in almost all sample types assayed (6.21 to $354.46 \mathrm{mg} \mathrm{kg}^{-1}$, Table 7) including demeclocycline and doxycycline (antibiotics reserved for specific cases in human therapy, Granados-Chinchilla and Rodríguez 2017) and 4-epioxytetracycline (which may indicate feed has reached its shelf life, Granados-Chinchilla et al. 2012). Tetracyclines can be used in most production animals, have a prophylactic effect against $C$. perfringens and Escherichia coli, it is also used to control infections caused by Mycoplasma, in concentrations of 200-400 $\mathrm{mg} \mathrm{kg}-1$ in aviculture with minimum withdrawal period of $24 \mathrm{~h}$ before the slaughterhouse (FDA 2011; Rojek-Podgórska 2016; Mehdi et al. 2018).

\section{Residues found in batch-to-batch cleaning or flushing samples}

During feed production, shift between mediated and non-medicated batches, a two-step flushing is among the practices recommended (using a cheap excipient material; e.g., cornmeal, calcium carbonate) to reduce antimicrobial traces (FDA 2013; Rojek-Podgórska 2016; Martínez et al. 2018). During batch-to-batch cleanup, a reduction in the concentration of antibiotics can be observed in line with the cleaning cycles (Table 8). From the samples tested, four sets of data were collected regarding flushing (monensin in all four cases, and florfenicol, erythromycin and narasin in only one of the cases). In three of the four cases of monensin, the initial quantity of coccidiostat was reduced to undetectable limits. For example, in the first case a calcium salt was used as a vehicle for flushing the monensin salt, and the original concentration of monensin $\left(907.40 \mathrm{mg} \mathrm{kg}^{-1}\right.$ ) was reduced to $2.07 \%$. In the second case, three cleaning cycles were used, two with finished feed and a final cycle with ground corn, here the initial concentration reported (741.45 $\mathrm{mg} \mathrm{kg}^{-1}$ ), was reduced to $22.02 \%$ in the second cycle and reached undetectable levels in the third cycle. In the third case, another type of feed was used as a vehicle for flushing, with negative results, where the initial amount went from $26.82 \mathrm{mg} \mathrm{kg}^{-1}$ to $20.11 \mathrm{mg} \mathrm{kg}^{-1}$. In the last case, in which corn meal was used in the first cycle and feed for the next two, it was possible to reduce the initial concentration $\left(13.82 \mathrm{mg} \mathrm{kg}^{-1}\right.$ ) to $1.88 \%$ (Table 8). Florfenicol reduction using the same strategy reduced $85.50 \%$ of the antibiotic. A second clean up cycle did not prove to be effective in reducing further the active ingredient. Florfenicol flushing seems to be challenging, probably due to interactions with the mixer, and cleaning batch vehicle as is a charged and halogenated molecule. Florfenicol residues do not comply even if the currently discussed thresholds expected after flushing are considered (i.e., maximum 3\% carry-over) (Rojek-Podgórska 2016). Finally, erythromycin and narasin were reduced from the first cleaning cycle with corn meal (Table 8). 


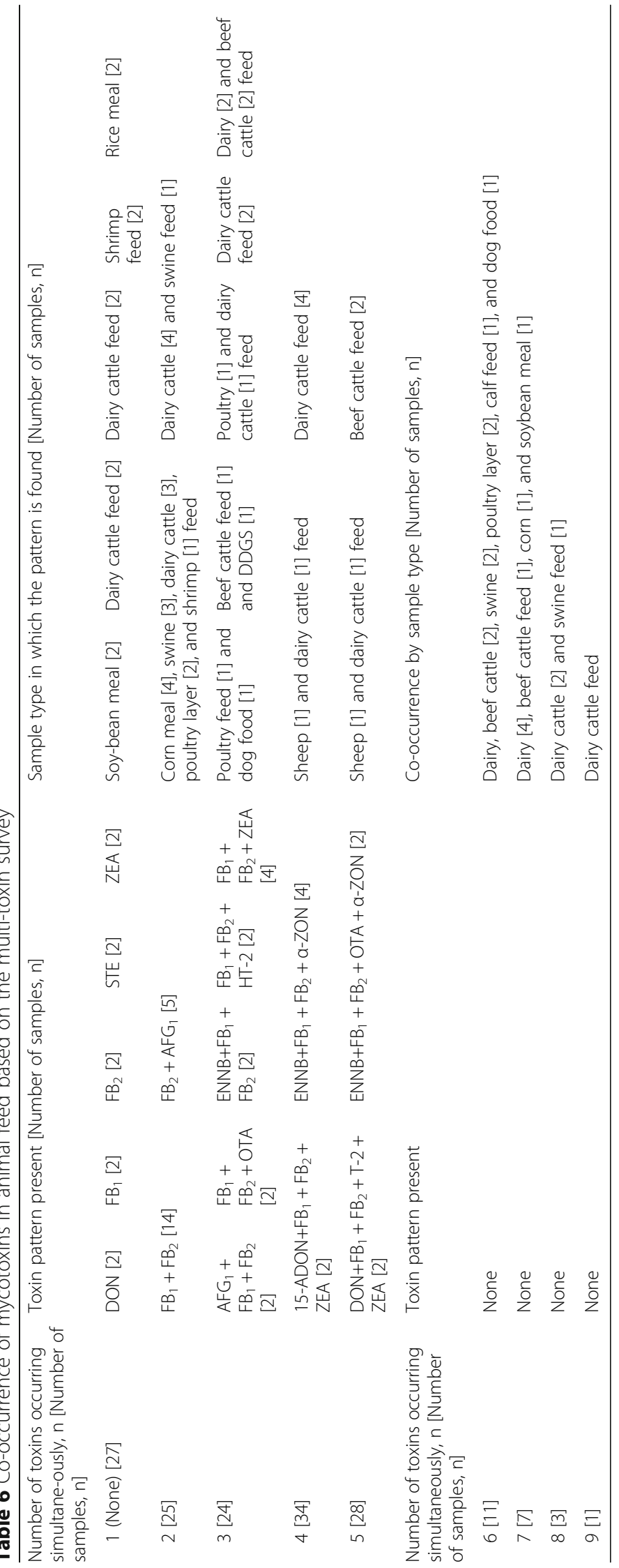



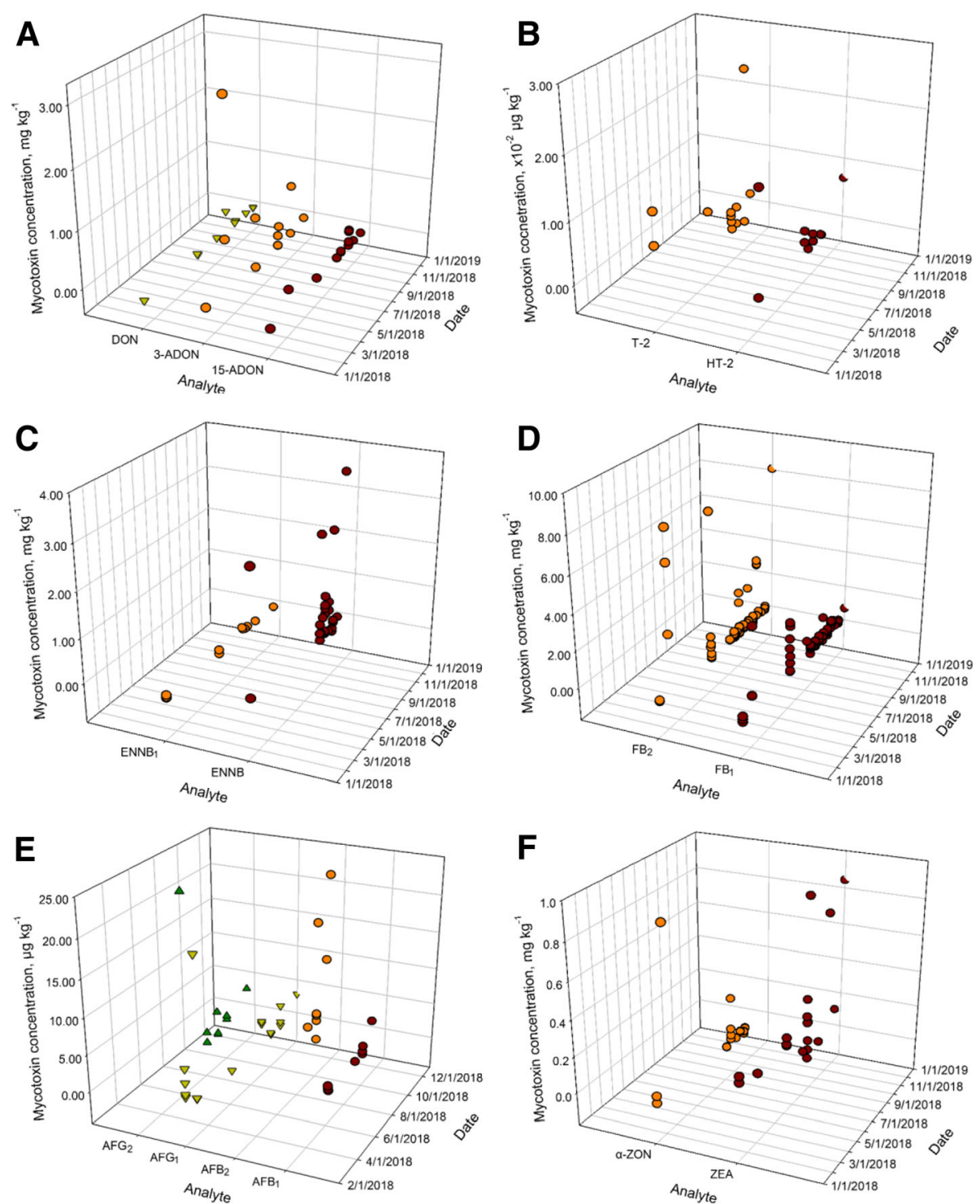

Fig. 4 Seasonal distribution and mycotoxins levels found in animal feed a Six tricothecenes: DON $\nabla, 3-A D O N O$, and 15-ADON and $H T$-2 toxin . c Two cyclic depsipeptides: ENNB $_{1} \longrightarrow$, and ENNB d Two polyketide-derived toxins: $\mathrm{FB}_{2}$, , and $\mathrm{FB}_{1}$

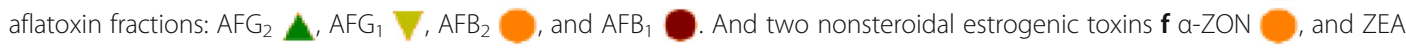

Incongruences on residues found in feed labeled as medicated may result from poor homogenization or use of low-quality feed antibiotics (Granados-Chinchilla and Rodríguez 2017). Adequate mixing is a critical step during feed milling, especially for micro-ingredients. Mixer overfilling and deposits from the mixer, as well as, the sequence of ingredient addition and mixing time may influence the product (Stark and Jones 2009; Rocha et al. 2015; Huss et al. 2018; Martínez et al. 2018). Additionally, the antibiotic residue found in feed labeled as non-medicated can be attributed to errors in labeling or batch to batch cross-contamination (Stolker et al. 2013; Seró et al. 2015; Filippitzi et al. 2016).
Contamination can also occur within the production flow (Martínez et al. 2018) or during the simultaneous transport and storage of medicated and non-medicated feed (Stark and Jones 2009). Antimicrobial under or overdosing can be equally damning as can generate adverse health effects and favors microbial resistance (Rojek-Podgórska 2016; Martínez et al. 2018).

\section{Conclusion}

During this survey, we found a worrisome prevalence of fumonisins in animal feed. Also, simultaneous contamination of feed with fumonisin fractions (e.g., $B_{1}$, and $B_{2}$ ) was quite frequent. Synergistic effect between 
Table 7 Antibiotic residues found in Costa Rican animal feed after routine inspections

\begin{tabular}{|c|c|c|c|c|}
\hline Animal feed & \multicolumn{2}{|l|}{ Phase } & Antibiotic & Concentration $\left(\mathrm{mg} \mathrm{kg}^{-1}\right)$ \\
\hline \multicolumn{5}{|c|}{ Medicated Animal feed [Number of prevalent samples, n] } \\
\hline \multirow[t]{7}{*}{ Poultry feed [2] } & \multirow{3}{*}{\multicolumn{2}{|c|}{ Start ${ }^{c, d}$}} & Tetracycline & 7.39 \\
\hline & & & Florfenicol & 80.07 \\
\hline & & & Narasin & 227.68 \\
\hline & \multirow{4}{*}{\multicolumn{2}{|c|}{ Growth $^{c}$}} & Tetracycline & 26.93 \\
\hline & & & Florfenicol & 287.51 \\
\hline & & & Doxycycline & 68.54 \\
\hline & & & Narasin & 44.03 \\
\hline \multirow[t]{2}{*}{ Pig feed [1] } & \multirow{2}{*}{\multicolumn{2}{|c|}{ Final $^{c}$}} & Tetracycline & 5.45 \\
\hline & & & Narasin & 2.04 \\
\hline \multicolumn{5}{|c|}{ Non-medicated Animal feed [Number of prevalent samples, n] } \\
\hline \multirow[t]{7}{*}{ Poultry feed [22] } & \multirow{3}{*}{\multicolumn{2}{|c|}{ Start [3] }} & Tetracycline & 30.61 \\
\hline & & & Monensina & $23, .0$ \\
\hline & & & Narasina & $36,517.25$ \\
\hline & \multicolumn{2}{|l|}{ Growth [3] } & Monensin & $163.25-13.84$ \\
\hline & \multirow{2}{*}{\multicolumn{2}{|c|}{ Final [4] }} & Tetracycline & 13.65 \\
\hline & & & Monensin [3] & $37.05-0.45$ \\
\hline & \multicolumn{2}{|l|}{ Layer [12] } & Monensin & 191.69-7.34 \\
\hline \multirow[t]{7}{*}{ Pig feed [19] } & \multicolumn{2}{|l|}{ Start [3] } & Monensin & $20.51-25.69$ \\
\hline & \multirow{4}{*}{\multicolumn{2}{|c|}{ Growth [11] }} & Tetracycline & 6.21 \\
\hline & & & Demeclocycline & 354.46 \\
\hline & & & Narasin & 142.55 \\
\hline & & & Monensin [8] & $49.03-5.17$ \\
\hline & \multirow{2}{*}{\multicolumn{2}{|c|}{ Final [5] }} & Tetracycline [2] & $12.21-10.76$ \\
\hline & & & Monensin [3] & $27.91-22.99$ \\
\hline \multirow[t]{2}{*}{ Fish and shrimp feed [5] } & \multirow{2}{*}{\multicolumn{2}{|c|}{ Not indicated }} & 4-epioxitetracycline & 159.94 \\
\hline & & & Monensin [4] & $741.45-13.36$ \\
\hline Dairy cattle feed [2] & \multicolumn{2}{|l|}{ Not indicated } & Monensin & $3258.86-57.04$ \\
\hline Horse feed [1] & \multicolumn{2}{|l|}{ Not indicated } & Doxycycline & 101.86 \\
\hline Raw material [1] & \multicolumn{2}{|l|}{ Corn meal } & Monensin & 27.25 \\
\hline \multicolumn{5}{|l|}{ Summary } \\
\hline Average $\pm S D$ & Median & Max & Min & Prevalence, \% [Samples below \\
\hline \multicolumn{5}{|l|}{ Concentration, $\mathrm{mg} \mathrm{kg}^{-1}$} \\
\hline \multicolumn{5}{|l|}{ 4-epianhydrotetracycline } \\
\hline$(1.21 \pm 1.97) \times 10^{1}$ & $1.21 \times 10^{1}$ & $1.23 \times 10^{1}$ & $1.19 \times 10^{1}$ & $2.22[88]$ \\
\hline Doxycycline & & & & \\
\hline $1.66 \times 10^{2} \pm 6.38 \times 10^{1}$ & $1.66 \times 10^{2}$ & $2.29 \times 10^{2}$ & $1.02 \times 10^{2}$ & $2.22[88]$ \\
\hline Florfenicol & & & & \\
\hline$(1.09 \pm 1.17) \times 10^{3}$ & $4.52 \times 10^{2}$ & $3.12 \times 10^{3}$ & $3.53 \times 10^{2}$ & $4.44[86]$ \\
\hline Narasin & & & & \\
\hline$(2.73 \pm 8.26) \times 10^{3}$ & $5.89 \times 10^{1}$ & $3.65 \times 10^{4}$ & $9.00 \times 10^{-1}$ & $24.44[68]$ \\
\hline Monensin & & & & \\
\hline$(1.57 \pm 4.99) \times 10^{2}$ & $2.33 \times 10^{1}$ & $3.26 \times 10^{3}$ & $2.57 \times 10^{-1}$ & 58.89 [37] \\
\hline
\end{tabular}


Table 7 Antibiotic residues found in Costa Rican animal feed after routine inspections (Continued)

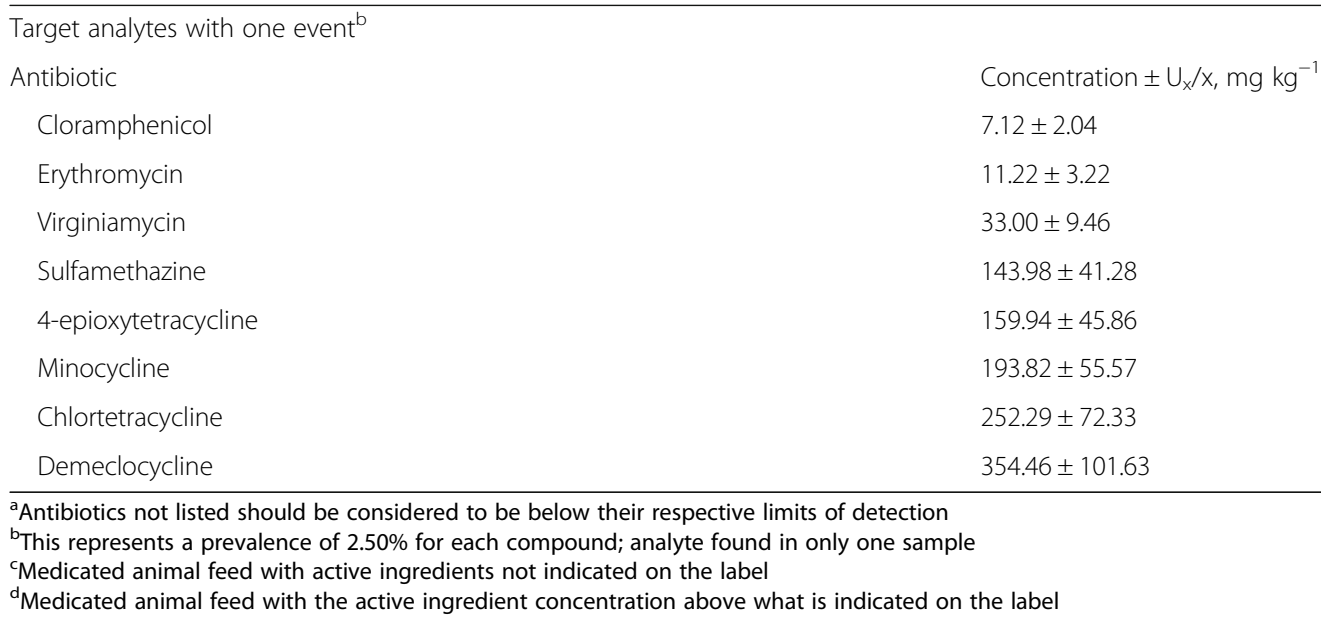

toxins must be considered, especially as the co-occurrence of fumonisin with other Fusarium sp. toxins is a real possibility. In the case of antibiotics, we still encountered several practices that contravene antimicrobial stewardship policies. We found feed tabulated as non-medicated with considerable concentrations of antibiotics, even if certain antimicrobials (or their mixtures) are outlawed in feeds, we also found feed samples with a wrong antimicrobial dosage or incorrect compound. Methods used in this work

Table 8 Field samples tested to demonstrate batch flushing efficiency

\begin{tabular}{|c|c|c|}
\hline Assay number & Sample ID & Concentration, $\mathrm{mg} \mathrm{kg}^{-1}$ \\
\hline \multicolumn{3}{|l|}{ Monensin } \\
\hline \multirow[t]{2}{*}{1} & Suckling pig feed, medicated & $907.40 \pm 260.16$ \\
\hline & Calcium (cleaning batch) & $18.80 \pm 5.39$ \\
\hline \multirow[t]{3}{*}{2} & Fish feed (tilapia and trout, 1st cleaning batch) & $741.45 \pm 212.58$ \\
\hline & Fish feed (tilapia and trout, 2nd cleaning batch) & $163.25 \pm 46.81$ \\
\hline & Ground corn (cleaning batch) & Not detected, $<4.09 \times 10^{-2}$ \\
\hline \multirow[t]{3}{*}{3} & Feed ingredient (1st cleaning batch) & $26.82 \pm 7.69$ \\
\hline & Compound feed (2nd cleaning batch) & $22.46 \pm 6.44$ \\
\hline & Compound feed (3rd cleaning batch) & $20.11 \pm 5.77$ \\
\hline \multirow[t]{3}{*}{4} & Corn meal (cleaning batch) & $13.82 \pm 3.96$ \\
\hline & Layer hen feed (1st batch) & $0.53 \pm 0.15$ \\
\hline & Layer hen feed (2nd batch) & $0.26 \pm 0.07$ \\
\hline \multicolumn{3}{|l|}{ Florfenicol } \\
\hline \multirow[t]{3}{*}{1} & Fish feed (tilapia and trout, 1st cleaning batch) & $3118.32 \pm 894.05$ \\
\hline & Fish feed (tilapia and trout, 2nd cleaning batch) & $452.13 \pm 129.63$ \\
\hline & Ground corn (cleaning batch) & $352.90 \pm 101.18$ \\
\hline \multicolumn{3}{|l|}{ Erythromycin } \\
\hline \multirow[t]{3}{*}{4} & Corn meal (cleaning batch) & $11.22 \pm 3.22$ \\
\hline & Layer hen feed (1st batch) & Not detected, $<8.09 \times 10^{-2}$ \\
\hline & Layer hen feed (2nd batch) & Not detected, $<8.09 \times 10^{-2}$ \\
\hline \multicolumn{3}{|l|}{ Narasin } \\
\hline \multirow[t]{3}{*}{4} & Corn meal (cleaning batch) & $9.50 \pm 2.72$ \\
\hline & Layer hen feed (1st batch) & $0.90 \pm 0.26$ \\
\hline & Layer hen feed (2nd batch) & Not detected, $<2.46 \times 10^{-2}$ \\
\hline
\end{tabular}


for the analysis of mycotoxins and antibiotics in animal feeds, are versatile and can still be improved and extended to the identification of more analytes of relevance in the livestock industry. Mycotoxins epidemiological data, diagnostic ability and capability, and knowledge of the behavior of mycotoxins is among the first steps to reduce mycotoxins for compound feed manufacturing. Good manufacturing practices are the base to guarantee feed safety, therefore, the design and implementation of the procedures that help avoid deviations on the concentration of the declared veterinary antibiotic on the label, and prevent production and animal and human health issues. Current legislation does not seek to prohibit the use of antibiotics in livestock production, its primary objective is the prudent use of antibiotics and to strengthen biosecurity practices within the animal production unit. Constant programs for monitoring contaminants, both from the natural and anthropogenic origin, found in feed, must continue to be encouraged. Finally, it is unclear what consequence the presence of additional xenobiotic or additives have over other contaminants and residues such as mycotoxins and antibiotics or if further detrimental health effects are to be expected from samples with both types of substances.

\section{Abbreviations \\ AAFCO: Association of American Feed Control Officials; ACN: Acetonitrile; EC: European community; EFSA: European Food Safety Authority; FA: Formic acid; FAO: Food and Agriculture Organization of the United Nations; FDA: Food and drug administration; HLB: Hydrophilic-lipophilic balance; LC: Liquid chromatography; MeOH: Methanol; MS: Mass spectrometry; SD: Standard deviation; SPE: Solid phase extraction; US: United States of America; WHO: World Health Organization}

\section{Acknowledgements}

Not applicable.

\section{Funding}

Vicerrectoría de Investigación supported this initiative financially.

\section{Availability of data and materials}

Collected and analysed data are available upon request from the corresponding author.

\section{Authors' contributions}

All authors contributed to the analysis, writing and improvement of the manuscript. All authors read and approved the final manuscript.

\section{Competing interests}

The authors declare that they have no competing interests.

\section{Publisher's Note}

Springer Nature remains neutral with regard to jurisdictional claims in published maps and institutional affiliations.

\section{Author details}

${ }^{1}$ Centro de Investigación en Nutrición Animal (CINA), Universidad de Costa Rica, 11501-2060 Ciudad Universitaria Rodrigo Facio, San José, Costa Rica. ${ }^{2}$ Centro de Investigación en Enfermedades Tropicales (CIET) and Facultad de Microbiología, Universidad de Costa Rica, 11501-2060 Ciudad Universitaria
Rodrigo, San José, Costa Rica. ${ }^{3}$ Escuela de Zootecnia, Universidad de Costa Rica, 11501-2060, Ciudad Universitaria Rodrigo Facio, San José, Costa Rica.

Received: 25 February 2019 Accepted: 16 April 2019

Published online: 25 June 2019

\section{References}

Abdallah MF, Girgin G, Baydar T, Krskaa R, Sulyoka M. Occurrence of multiple mycotoxins and other fungal metabolites in animal feed and maize samples from Egypt using LC-MS/MS. J Sci Food Agric. 2017;97:4419-28. https://doi. org/10.1002/JSFA.8293.

Abdou K, Hassan A, Hassan N, Houda R. Seasonal variation in prevalence of mycotoxins in feed and feedstuffs at Beni-Suef governorate in Egypt. Eur J Acad Essays. 2017:4:99-109.

Alassane-Kpembi I, Schatzmayr G, Taranu I, Marin D, Puel O, Oswald IP. Mycotoxins co-contamination: methodological aspects and biological relevance of combined toxicity studies. Crit Rev Food Sci Nutr. 2017;57:3489-507. https://doi. org/10.1080/10408398.2016.1140632.

Alshannaq A, Yu JH. Occurrence, toxicity, and analysis of major mycotoxins in food. Int J Environ Res Public Health. 2017;14:1-20. https://doi.org/10.3390/ ijerph14060632.

Anadón A, Martínez-Larrañaga M, Ares I, Martínez M. Chapter 7 - regulatory aspects for the drugs and chemicals used in food-producing animals in the European union. In: Veterinary toxicology (third edition) basic and clinical principles; 2018. p. 103-31. https://doi.org/10.1016/B978-0-12-811410-0.00007-6.

Association of American Feed Control Officials. Feed inspector's manual. Oxfordshire: Association of American Feed Control Officials, Inspection and Sampling Committee (AAFCO); 2017.

Berthiller F, Crews C, Dall'Asta C, De Saeger S, Haesaert G, Karlovsky P, Oswald IP, Seefelder W, Speijers G, Stroka J. Masked mycotoxins: a review. Mol Nutr Food Res. 2013;57:165-86. https://doi.org/10.1002/mnfr.201100764.

Beukers AG, Zaheer R, Cook SR, Stanford K, Chaves AV, Ward MP, McAllister TA. Effect of in-feed administration and withdrawal of tylosin phosphate on antibiotic resistance in enterococci isolated from feedlot steers. Front Microbiol. 2015;24:483. https://doi.org/10.3389/fmicb.2015.00483.

Bezerra da Rocha ME, da Chagas F, Maia FEF, Guedes MIF, Rondinan D. Mycotoxins and their effects on human and animal health. Food Control. 2014;36:159-65.

Blandino M, Scarpino V, Giordano D, Sulyok M, Krska R, Vanara F, Reyneri A. Impact of sowing time, hybrid and environmental conditions on the contamination of maize by emerging mycotoxins and fungal metabolites. Ital J Agron. 2017;12:215-24. https://doi.org/10.4081/ija.2017.928.

Boix C, Ibáñez M, Sancho JV, León N, Yusá V, Hernández F. Qualitative screening of 116 veterinary drugs in feed by liquid chromatography-high resolution mass spectrometry: potential application to quantitative analysis. Food Chem. 2014;160:313-20

Borman P, Elder D. ICH Quality Guidelines: An Implementation Guide, First Edition. Edited by Andrew Teasdale, David Elder, and Raymond W. Nims. (C) 2018 John Wiley \& Sons, Inc. 2018.

Bozzo G, Bonerba E, Ceci E, Colao V, Tantillo G. Determination of ochratoxin a in eggs and target tissues of experimentally drugged hens using HPLC-FLD. Food Chem. 2011;126:1278-82.

Burel C, Tanguy M, Guerre P, Boilletot E, Cariolet R, Queguiner M, Postollec G, Pinton P, Salvat G, Osawald IP, Fravalol P. Effect of low dose of Fumonisins on pig health: immune status, intestinal microbiota and sensitivity to Salmonella. Toxins (Basel). 2013;5:841-64. https://doi.org/10.3390/ toxins5040841.

Cancho Grande B, García Falcón MS, Simal Gándara J. El uso de los antibióticos en la alimentación animal: perspectiva actual. CyTA J Food. 2000;3:39-47. https://doi.org/10.1080/11358120009487647.

Codex Alimentarius INternational Food Standards. CAC/RCP 51-2003 Code of Practice for the Prevention and Reduction of Mycotoxin Contamination in Cereals, including Annexes on Ochratoxin A, Zearalenone, Fumonisins and Tricothecenes. Rome: Food and Agriculture Organization of the United Nations and World Health Organization; 2014. http://www.fao.org/input/ download/standards/406/CXP_051e_2014.pdf Accessed 9 May 2019

COMIECO [Consejo de Ministros de Integración Económica Centroamericana] RTCA 65.05.52:11 Productos utilizados en alimentación animal y establecimientos, requisitos de registro sanitario y control; 2012. p. 27. http:// visar.maga.gob.gt/visar/rtca5211.pdf. Accessed 10 July 2018 
De Ruyck K, De Boevre M, Huybrechts I, De Saeger S. Dietary mycotoxins, coexposure, and carcinogenesis in humans: short review. Mutat Res Rev Mutat Res. 2015;766:32-41.

Díaz-Nieto CH, Granero AM, Zon MA, Fernández H. Sterigmatocystin: a mycotoxin to be seriously considered. Food Chem Toxicol. 2018. https://doi.org/10. 1016/j.fct.2018.05.057.

Duelge KJ, Nishshanka U, De Alwis HG. An LC-MS/MS method for the determination of antibiotic residues in distillers grains. J Chromatogr B Analyt Technol Biomed Life Sci. 2017;1053:81-6. https://doi.org/10.1016/j. jchromb.2017.03.037

EFSA CONTAM Panel (EFSA Panel on Contaminants in the Food Chain). Scientific opinion on the risks for public and animal health related to the presence of citrinin in food and feed. EFSA J. 2012;10:2605. https://doi.org/10.2903/j.efsa. 2012.2605.

Escrivá L, Font G, Manyes L, Berrada H. Studies on the presence of mycotoxins in biological samples: an overview. Toxins (Basel). 2017;9:1-33. https://doi.org/ 10.3390/toxins9080251.

Eskola M, Altieri A, Galobart J. Overview of the activities of the European Food Safety Authority on mycotoxins in food and feed. World Mycotoxin. 2018;11: 277-89. https://doi.org/10.3920/wmj2017.2270.

European Commission. Directive 2001/82/EC of the European parliament and of the council of 6 November 2001 on the community code relating to veterinary medicinal products. Brussels: Official Journal of the European Communities; 2001. L 311/1-66. https://eur-lex.europa.eu/legal-content/EN/ TXT/PDF/?uri=CELEX:32001L0082\&from=ES. Accessed 10 July 2018

European Commission. (2004) Regulation (EC) No 726/2004 of the European parliament and of the council of 31 March 2004 laying down community procedures for the authorisation and supervision of medicinal products for human and veterinary use and establishing a European medicines agency. Brussels, Official Journal of the European Communities. L 136/1-33. https:// eur-lex.europa.eu/legal-content/EN/TXT/PDF/?uri=CELEX:32004R0726\&from= ES. Accessed 10 July 2018

FAO [Food and Agriculture Organization of the United Nations]. El estado mundial de la pesca y la acuicultura. Dirección de Información de la FAO; 2002. p. 150. http://www.fao.org/docrep/005/y7300s/y7300s00. htm\#TopOfPage. Accessed 21 July 2018

FAO [Food and Agriculture Organization of the United Nations]. (2018) Aquaculture feed and fertilizer resources information system. http://www.fao.org/fishery/ affris/species-profiles/nile-tilapia/tables/en/. Accessed 19 July 2018.

FDA [US Food and Drug Administration]. (2011) Feed additive compendium, USA.

FDA [US Food and Drug Administration]. Guidance for industry \#2013 new animal drugs and new animal drug combination products administered in or on medicated feed or drinking water of food producing animals: recommendations for drug sponsors for voluntarily aligning product use conditions with GFI \#209: U.S. Department of Health and Human Services; 2013. p. 18. https://www.fda.gov/downloads/AnimalVeterinary/ GuidanceComplianceEnforcement/Guidanceforlndustry/UCM299624.pdf. Accessed 19 July 2018

FDA [US Food and Drug Administration]. (2018) Medicated feeds. https://www fda.gov/AnimalVeterinary/Products/AnimalFoodFeeds/MedicatedFeed/ default.htm\#license. Accessed 19 July 2018.

FEDIAF. Nutritional guidelines for complete and complementary pet food for cats and dog. Brussels; 2016.

Fernandez-Blanco C, Elmo L, Waldner T, Ruiz MJ. Cytotoxic effects induced by patulin, deoxynivalenol and toxin T2 individually and in combination in hepatic cells (HepG2). Food Chem Toxicol. 2018;120: 12-23. https://doi.org/10.1016/j.fct.2018.06.019.

Filippitzi ME, Sarrazin S, Imberechts H, Smet A, Dewulf J. Risk of cross-contamination due to the use of antimicrobial medicated feed throughout the trail of feed from the feed mill to the farm. Food Addit Contam Part A Chem Anal Control Expo Risk Assess. 2016:33:644-55. https://doi.org/10.1080/19440049.2016.1160442.

Fink-Gremmels J. Mycotoxins in cattle feeds and carry-over to dairy milk: a review. Food Addit Contam Part A Chem Anal Control Expo Risk Assess. 2008;25:172-80. https://doi.org/10.1080/02652030701823142.

Gazzotti T, Biagi G, Pagliuca G, Pinna C, Scardilli M, Grandi M, Zaghini G. Occurrence of mycotoxins in extruded commercial dog food. Anim Feed Sci Technol. 2015;202:81-9. https://doi.org/10.1016/j.anifeedsci.2015.02.004.

Granados-Chinchilla F. A focus on aflatoxin in feedstuffs: new developments in analysis and detection, feed composition affecting toxin contamination, and interdisciplinary approaches to mitigate it. In: Abdulra'uf LB, editor. Aflatoxincontrol, analysis, detection and health risks. London: IntechOpen; 2017.
Granados-Chinchilla F, Molina A, Chavarría G, Alfaro-Cascante M, BogantesLedezma D, Murillo-Williams A. Aflatoxins occurrence through the food chain in Costa Rica: applying the one health approach to mycotoxin surveillance. Food Control. 2017;82:217-26. https://doi.org/10.1016/j.foodcont.2017.06.023.

Granados-Chinchilla F, Rodríguez C. Tetracyclines in food and feedingstuffs: from regulation to analytical methods, bacterial resistance, and environmental and health implications. J Anal Methods Chem. 2017;2017:1315497.

Granados-Chinchilla F, Sánchez J, García F, Rodríguez C. A novel green chemistry method for nonaqueous extraction and high-performance liquid chromatography detection of first-, second-, and third-generation tetracyclines, 4-epitetracycline, and tylosin in animal feeds. J Agric Food Chem. 2012;60:7121-8.

Gratz SW. Do plant-bound masked mycotoxins contribute to toxicity? Toxins (Basel). 2017:9:85. https://doi.org/10.3390/toxins9030085.

Hall P, Selinger B. A statistical justification relating Interlaboratory coefficients of variation with concentration levels. Anal Chem. 1989;61:1465-6. https://doi. org/10.1021/ac00188a033.

Heussner AH, Bingle LE. Comparative ochratoxin toxicity: a review of the available data. Toxins (Basel). 2015;7:4253-82. https://doi.org/10.3390/toxins7104253.

Horwitz W, Albert RJ. The Horwitz ratio (HorRat): a useful index of method performance with respect to precision. Assoc Off Anal Chem. 2006;89:1095-109.

Huss A, Cochrane R, Jones C, Atungulu G. Chapter 5 - physical and chemical methods for the reduction of biological hazards in animal feeds. In: Food and feed safety system and analysis; 2018. https://doi.org/10.1016/B978-0-12-811835-1.00005-1.

INRA. Equine nutrition. Wageningen: Wageningen Academic Publishers; 2012

Jonsson M, Jestoi M, Anthoni M, Welling A, Loivamaa I, Hallikainen V, Kankainen M, Lysøe E, Koivisto P, Peltonen K. Fusarium mycotoxin enniatin B: cytotoxic effects and changes in gene expression profile. Toxicol in Vitro. 2016;34:30920. https://doi.org/10.1016/j.tiv.2016.04.017.

Kant V, Singh P, Verma PK, Bains I, Parmar MS, Gopel A, Gupta V. Anticoccidial drugs used in the poultry: an overview. Sci Intl. 2013;1:261-5. https://doi.org/ 10.5567/sciintl.2013.261.265

Karlovsky P, Suman M, Berthiller F, De Meester J, Eisenbrand G, Perrin I, Oswald IP Speijers G, Chiodini A, Recker T, Dussort P. Impact of food processing and detoxification treatments on mycotoxin contamination. Mycotox Res. 2016; 32:179-205. https://doi.org/10.1007/s12550-016-0257-7.

Kumar S, Chen C, Indugu N, Werlang GO, Singh M, Kim WK, Thippareddi H. Effect of antibiotic withdrawal in feed on chicken gut microbial dynamics, immunity, growth performance and prevalence of foodborne pathogens. PLoS One. 2018;13:e0192450. https://doi.org/10.1371/journal.pone.0192450.

Lee M, Seo DJ, Jeon SB, Ok HE, Jung H, Choi C, Chun HS. Detection of foodborne pathogens and mycotoxins in eggs and chicken feeds from farms to retail markets. Korean J Food Sci Anim Resour. 2016;36:463-8. https://doi.org/10. 5851/kosfa.2016.36.4.463.

Liuzzi VC, Mirabelli V, Cimmarusti MT, Haidukowski M, Leslie JF, Logrico AF, Caliandro R, Fanelli F, Mulé G. Enniatin and Beauvericin biosynthesis in Fusarium species: production profiles and structural determinant prediction. Toxins. 2017;9. https://doi.org/10.3390/toxins9020045.

Malachová A, Stránská M, Václavíková M, Elliott CT, Black C, Meneely J, Hajšlová J, Ezekiel CN, Schuhmacher R, Krska R. Advanced LC-MS-based methods to study the co-occurrence and metabolization of multiple mycotoxins in cereals and cereal-based food. Anal Bioanal Chem. 2017;410:801-25. https:// doi.org/10.1007/s00216-017-0750-7.

Manyes L, Escrivá L, Ruiz MJ, Juan-García A. Beauvericin and enniatin B effects on a human lymphoblastoid Jurkat T-cell model. Food Chem Toxicol. 2018;115: 127-35. https://doi.org/10.1016/j.fct.2018.03.008.

Marín S, Ramos AJ, Cano-Sancho G, Sanchis V. Mycotoxins: occurrence, toxicology, and exposure assessment. Food Chem Toxicol. 2013;60:218-37. https://doi.org/10.1016/j.fct.2013.07.047.

Martínez A, Jones CK, Stark CB, MacKinney L, Behnke KC, Paulk CB. Evaluating flushing procedures to prevent nicarbazin carryover during medicated feed manufacturing. Anim Feed Sci Tecnol. 2018;242:1-7. https://doi.org/10.1016/j. anifeedsci.2018.04.017.

Martínez Marín AL. Inclusion of feeds in pelleted concentrates intended for stallfed leisure horses. Arch Zootec. 2008;57:115-22.

Mehdi Y, Létourneau-Montminy M, Gaucher M, Chorfi Y, Gayatri S, Rouissi T, Brar S, Côte C, Ramírez A, Godbout S. Use of antibiotics in broiler production: global impacts and alternatives. Anim Nutr. 2018. https://doi.org/10.1016/.aninu.2018.03.002.

Milićević DR, Škrinjar M, Baltić T. Real and perceived risks for mycotoxin contamination in foods and feeds: challenges for food safety control. Toxins (Basel). 2010;2:572-92. https://doi.org/10.3390/toxins2040572. 
Ministerio de Agricultura y Ganadería [MAG]. Decreto No. 16899 - MAG, Reforma Reglamento para el Control de la Elaboración y Expendio de Alimentos para Animales. San José; 1985. http://www.feednet.ucr.ac.cr/legal/decreto16899.htm. Accessed 10 July 2018

Ndemera M, Landschoot S, De Boevre M, Nyanga LK, De Saeger S. Effect of agronomic practices and weather conditions on mycotoxins in maize: a case study of subsistence farming households in Zimbabwe. World Mycotoxin J. 2018;11:421-36. https://doi.org/10.3920/wmj2017.2227.

Nesic K, Ivanovic S, Nesic V. Fusarial toxins: secondary metabolites of Fusarium fungi. Rev Environ Contam Toxicol. 2014;228:101-20. https://doi.org/10.1007/ 978-3-319-01619-1_5.

Njumbe EE, Van Poucke C, De Saeger S. A multi-analyte LC-MS/MS method for the analysis of 23 mycotoxins in diferent sorghum varieties: the forgoten sample matrix. Food Chem. 2015;177:397-404. https://doi.org/10.1016/j. foodchem.2015.01.060.

NRC. Nutrient requirements of dairy cattle. 7th ed. Washington, D.C.: National Academy Press; 2001.

Ostry V, Malir F, Toman J, Grosse Y. Mycotoxins as human carcinogens-the IARC monographs classification. Mycotoxin Res. 2017;33:65-73.

Payros D, Alassane-Kpembi I, Pierron A, Loiseau N, Pinton P, Oswald IP. Toxicology of deoxynivalenol and its acetylated and modified forms. Arch Toxicol. 2016;90:2931-57. https://doi.org/10.1007/s00204-016-1826-4.

Peng WX, Marshall JLM, Van der Poel AFB. Strategies to prevent and reduce mycotoxins for compound feed manufacturing. Anim Feed Sci Technol. 2018;237:129-53. https://doi.org/10.1016/j.anifeedsci.2018.01.017.

Pettersson H. In: Fink-Gremmels J, editor. Mycotoxin contamination of animal feed: Woodhead Publishing Series in Food Science, Technology and Nutrition, Animal Feed Contamination, Woodhead Publishing; 2012. https:// doi.org/10.1533/9780857093615.3.233. ISBN9781845697259.

Pietsch C, Kersten S, Burkhardt-Holm P, Valenta H, Dänicke S. Occurrence of deoxynivalenol and zearalenone in commercial fish feed: an initial study. Toxins (Basel). 2013;5:184-92. https://doi.org/10.3390/toxins5010184.

Pinotti L, Ottoboni M, Giromini C, Dell'Orto V, Cheli F. Mycotoxin contamination in the EU feed supply chain: a focus on cereal byproducts. Toxins (Basel). 2016;8:45. https://doi.org/10.3390/toxins8020045.

Rocha AG, Montanhini RN, Dilkin P, Tamiosso CD, Mallmann CA. Comparison of different indicators for the evaluation of feed mixing efficiency. Anim Feed Sci Tecnol. 2015;209:249-56. https://doi.org/10.1016/j.anifeedsci.2015.09.005.

Rojek-Podgórska B. EU legislation in progress: review of medicated feed legislation: European Parliamentary Research Service (EPRS); 2016. http:// www.europarl.europa.eu/RegData/etudes/BRIE/2016/583843/EPRS_ BRI\%282016\%29583843_EN.pdf. Accessed 10 July 2018

Rostagno H, Teixeira L, Hannas M, Lopes J, Kazue N, Perazzo F, Saraiva A, Teixeira de Abreu M, Borges P, Flávia De Oliveira R, Luiz de Toledo Barreto S, de Oliveira C. Tablas brasileñas para aves y cerdos. 4th ed. Viçosa: Universidad Federal de Viçosa, Departamento de zootecnia; 2017.

Schertz H, Kluess J, Frahm J, Schatzmayr D, Dohnal I, Bichl G, Schwartz-Zimmermann $H$, Breves $G$, Dänicke S. Oral and intravenous fumonisin exposure in pigs-a single-dose treatment experiment evaluating toxicokinetics and detoxification. Toxins (Basel). 2018;10:E150. https://doi.org/10.3390/toxins10040150.

Seró R, Núñez O, Bosch J, Grases JM, Rodríquez P, Moyano E, Galceran MT. Desorption electrospray ionization-high resolution mass spectrometry for the screening of veterinary drugs in cross-contaminated feedstuffs. Anal Bioanal Chem. 2015;407:7369-78. https://doi.org/10.1007/s00216-015-8899-4.

Sospedra I, Blesa J, Soriano JM, Mañes J. Use of the modified quick easy cheap effective rugged and safe sample preparation approach for the simultaneous analysis of type A- and B-trichothecenes in wheat flour. J Chromatogr A. 2010;1217:1437-40. https://doi.org/10.1016/j.chroma.2009.12.047.

Stark C, Jones F. Quality assurance program in feed manufacturing. Feedstuffs. 2009:60-5 http://fdsmagissues.feedstuffs.com/fds/Reference_issue_2010/ Reference_issue_2009/11_Quality\%20assurance.pdf

Stolker AAM, Manti V, Zuidema T, van Egmond H, Decker ER, Herbes R, Hooglugt J, Olde Heuvel E, de Jong J. Carry-over of veterinary drugs from medicated to nonmedicated feeds in commercial feed manufacturing plants. Food Addit Contam Part A Chem Anal Control Expo Risk Assess. 2013;30:1100-7. https://doi.org/10.1080/19440049.2013.794308.

Streit E, Schatzmayr G, Tassis P, Tzika E, Marin D, Taranu I, Tabuc C, Nicolau A, Aprodu I, Puel O, Oswald IP. Current situation of mycotoxin contamination and co-occurrence in animal feed-focus on Europe. Toxins (Basel). 2012;4: 788-809. https://doi.org/10.1080/10.3390/toxins4100788.
Streit E, Schwab C, Sulyok M, Naehrer K, Krska R, Schatzmayr G. Multi-mycotoxin screening reveals the occurrence of 139 different secondary metabolites in feed and feed ingredients. Toxins (Basel). 2013;5:504-23. https://doi.org/10. 1080/10.3390/toxins5030504.

Tang KL, Caffrey NP, Nóbrega DB, Cork SC, Ronksley PE, Barkema HW, Polachek AJ, Ganshorn H, Sharma N, Kellner JD, Ghali WA. Restricting the use of antibiotics in food-producing animals and its associations with antibiotic resistance in food-producing animals and human beings: a systematic review and meta-analysis. Lancet Planet Health. 2017;1:e316-27. https://doi.org/10. 1016/S2542-5196(17)30141-9.

Thomson M. Limitations of the application of the Horwitz equation: a rebuttal. Trends Anal Chem. 2007;26:659-61.

US FDA. Analytical procedures and methods validation for drugs and biologics, guidance for industry. 2015. Available from: https://www.fda.gov/downloads/ drugs/guidances/ucm386366.pdf. Cited 1 Aug 2018.

van der Fels-Klerx HJ, Adamse P, Punt A, van Asselt ED. Data analyses and modelling for risk based monitoring of mycotoxins in animal feed. Toxins. 2016b;10:E54

van der Fels-Klerx HJ, Liu C, Battilani P. Modelling climate change impacts on mycotoxin contamination. World Mycotox J. 2016a;9:717-26. https://doi.org/ 10.3920/WMJ2016.2066.

Viegas C, Nume J, Piecková E, Viegas S. Sterigmatocystin in foodstuffs and feed: aspects to consider. Mycology. 2018. https://doi.org/10.1080/21501203.2018. 1492980

Wang Y, Xiao C, Guo J, Yuan Y, Wang J, Liu L, Yue T. Development and application of a method for the analysis of 9 mycotoxins in maize by HPLCMS/MS. J Food Sci. 2013;78:1752-6. https://doi.org/10.1111/1750-3841.12187.

Warth B, Parich A, Atehnkeng J, Bandyopadhyay R, Schuhmacher R, Sulyok M, Krska R. Quantitation of mycotoxins in food and feed from Burkina Faso and Mozambique using a modern LC-MS/MS multitoxin method. J Agric Food Chem. 2012;60:9352-63. https://doi.org/10.1021/jf302003n.

WHO [World Health Organization]. Global action plan on antimicrobial resistance: WHO Library Cataloguing; 2015. http://www.wpro.who.int/entity/drug_ resistance/resources/global_action_plan_eng.pdf. Accessed 18 July 2018

Wu F, Groopman JD, Pestka JJ. Public health impacts of foodborne mycotoxins. Annu Rev Food Sci Technol. 2014;5:351-72. https://doi.org/10.1146/annurevfood-030713-092431.

Zain ME. Impact of mycotoxins on humans and animals. J Saudi Chem Soc. 2011; 15:129-44.

Zbyňovská K, Petruška P, Kalafová A, Capcarová M. Patulin - a contaminant of food and feed: a review. Acta Fytotechn Zootechny. 2016;19:64-7.

Zhou H, George S, Hay C, Lee J, Qian H, Sun X. Individual and combined effects of aflatoxin $B_{1}$, Deoxynivalenol and Zearalenone on HepG2 and RAW 264.7 cell lines. Food Chem Toxicol. 2017;103:18-27.

\section{Ready to submit your research? Choose BMC and benefit from:}

- fast, convenient online submission

- thorough peer review by experienced researchers in your field

- rapid publication on acceptance

- support for research data, including large and complex data types

- gold Open Access which fosters wider collaboration and increased citations

- maximum visibility for your research: over $100 \mathrm{M}$ website views per year

At $\mathrm{BMC}$, research is always in progress.

Learn more biomedcentral.com/submissions 